University for Business and Technology in Kosovo

UBT Knowledge Center

Theses and Dissertations

Student Work

4-2019

\title{
An Empirical Study about the Impact of Internet in SMES
}

Albert Aliu

University for Business and Technology - UBT

Follow this and additional works at: https://knowledgecenter.ubt-uni.net/etd

Part of the Management Information Systems Commons

\section{Recommended Citation}

Aliu, Albert, "An Empirical Study about the Impact of Internet in SMES" (2019). Theses and Dissertations.

5.

https://knowledgecenter.ubt-uni.net/etd/5

This Thesis is brought to you for free and open access by the Student Work at UBT Knowledge Center. It has been accepted for inclusion in Theses and Dissertations by an authorized administrator of UBT Knowledge Center. For more information, please contact knowledge.center@ubt-uni.net. 


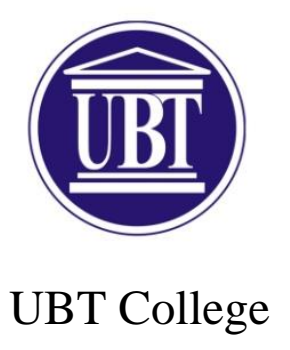

Faculty of Information Systems

\section{AN EMPIRICAL STUDY ABOUT THE IMPACT OF INTERNET IN SMES \\ Master degree}

Albert Aliu

April, 2019

Prishtina, Republic of Kosovo 


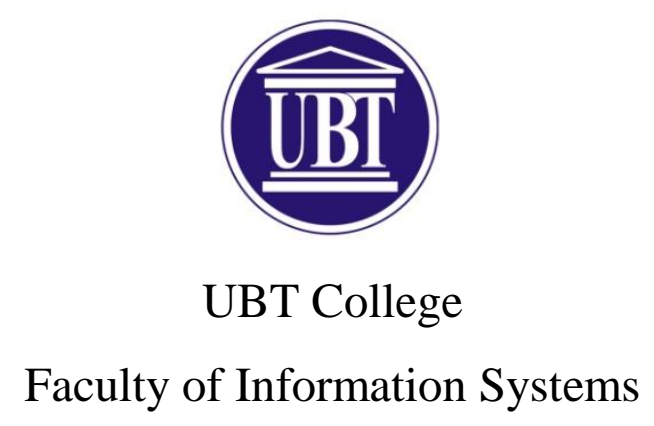

Thesis

Academic year 2016/2017

\begin{abstract}
Albert Aliu
AN EMPIRICAL STUDY ABOUT THE IMPACT OF INTERNET IN SMES

Master degree
\end{abstract}

Co-Mentor: PhD. Hasan Metin

Co-Mentor: Prof. Dr. Edmond Hajrizi

April, 2019

This paper has been compiled and submitted to meet the partial requirements for the Master Degree 


\section{ABSTRACT}

The aim of this research was to find out the current trends of usage of new technologies, with a special focus on the impact of the Internet based on chosen variables. The target group of the current research were small to medium size enterprises - SMEs, which are considered as the most-influential entities within a country. This is due to their influence on economy and employment opportunities they offer in every country. The results of this research show a better image about the current technological trends in Kosovo and no other research with identic approach was found out by the researcher.

Assessing the impact of technology within SMEs through quantitative approach was selected as the most appropriate method to estimate and evaluate the current trends. A structured questionnaire was used as the main instrument to gather the primary data. The questionnaire was distributed by the researcher to a random sample of 140 enterprises around Kosovo. A second visit individually to each enterprise was accomplished and a response rate of $67 \%$ was secured from the respective respondents, which gave the researcher the opportunity to conduct statistical analysis. Descriptive statistics have shown changes in enterprise management in regards to gender, age and sustainability. Procedures in governmental entities in comparison to neighbour countries were less bureaucratic. Also, the majority of enterprises are influenced by the new technologies in everyday business activities, especially by the use of the Internet to interact with third parties.

Furthermore, with a correlation as the main statistical measure it was found out that the good location is not correlated with being online and with necessity of incentives from government. While the good location is correlated with benefits of the Internet in comparison to its cost. Similarly, it was found that necessity of being online is correlated with the necessity of incentives from government as well as with benefits of the Internet in comparison to its cost. Moreover, it was found that necessity of incentives from government is correlated with benefits of the Internet in comparison to its cost.

Based on the results of the research, it can be concluded that the role of the new technologies and the Internet is re-shaping the business model of the enterprises faster than any oth- 
er factors.

Keywords: ICT, SMEs, Information Technology, Information Systems, IS, Internet. 


\section{ACKNOWLEDGMENTS}

I want to express my gratitude to my supervisors Prof. Dr. Hasan Metin and Prof. Dr. Edmond Hajrizi for their continuous support they provided since the very beginning of my research idea as well as during the whole process.

I also owe my thanks to all my family, friends and associates who helped me with the completion of this research.

Albert Aliu

January, 2019 


\section{TABLE OF CONTENTS}

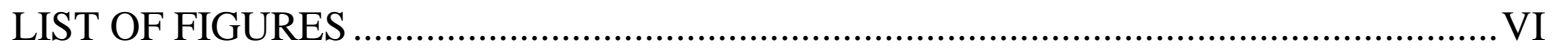

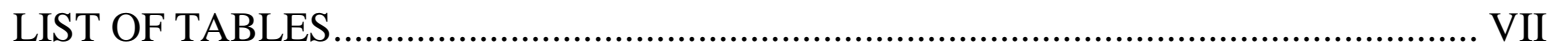

LIST OF ABBREVIATIONS ........................................................................................ VIII

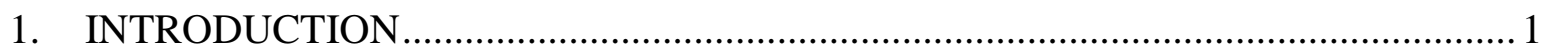

2. LITERATURE REVIEW .............................................................................. 3

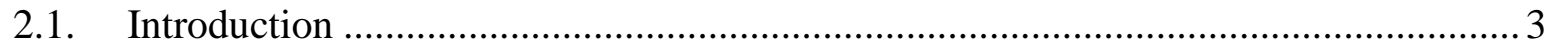

2.2. Impact of Small to Medium Enterprise in a society ……............................................ 3

2.2.1. SMEs in Balkan Peninsula ............................................................................. 4

2.2.2. Opportunities and barriers of SMEs in Balkan Peninsula ....................................5

2.3. Evolution of Information and Communication Technology services ........................... 8

2.3.1. Technological opportunities of SMEs ............................................................

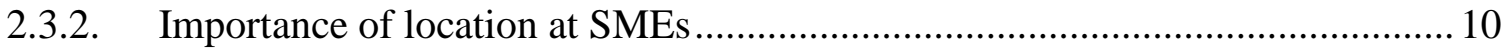

2.4. Impact of Information Systems in SMEs located in Balkan Peninsula ..................... 12

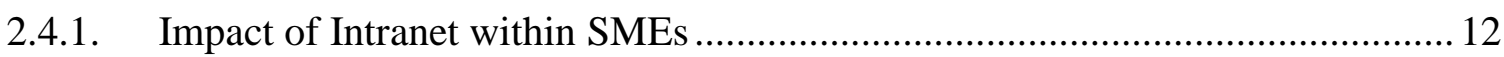

2.4.2. Advanced Information Systems within SMEs .................................................... 13

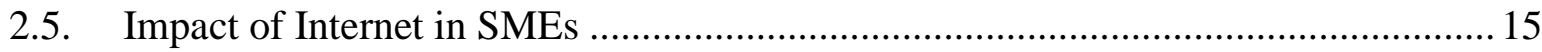

2.5.1. Importance of government incentives on Internet infrastructure ........................ 16

2.5.2. Customer satisfaction on online purchases - e-Commerce ................................ 17

2.5.3. Benefits of the Internet tend to outweigh its costs ............................................ 19

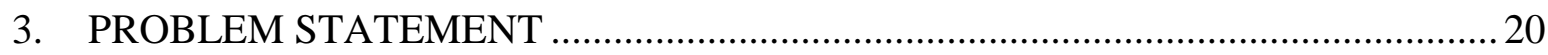

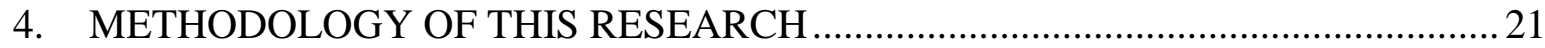

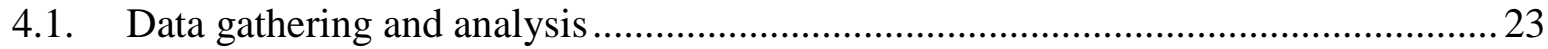

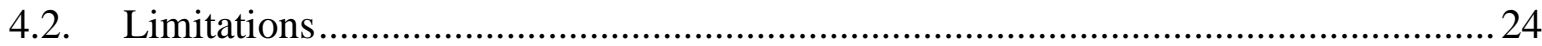

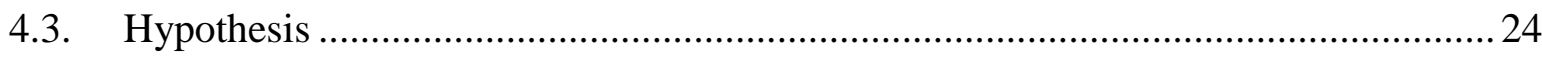

5. PRESENTATION AND ANALYSIS OF THE RESEARCH .......................................26

5.1. Results regarding the opportunities and decision making in SMEs ...........................26

5.2. Impact of Information and Communication Technology (ICT) at SMEs ...................30

5.3. Internal and external influence on the usage of the Internet and ICT at SMEs.......... 33

5.4. Current and future plans on using innovative solutions offered by the Internet ........35 
5.5. Interaction with third parties through the use of the Internet ............................... 36

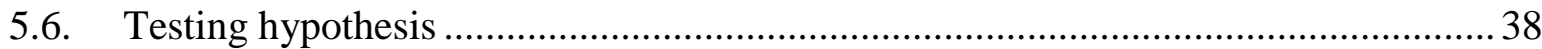

6. CONCLUSION, LIMITATIONS AND FUTURE STUDIES ................................ 41

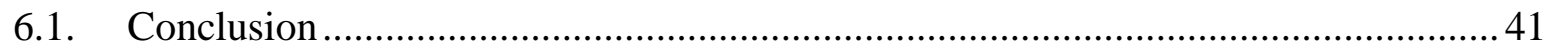

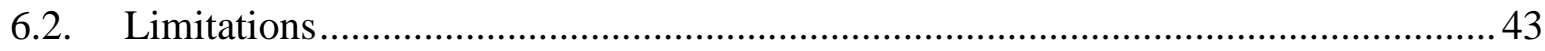

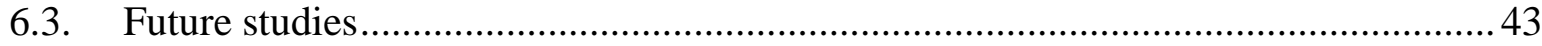

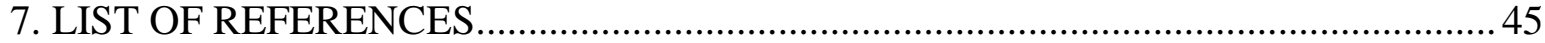

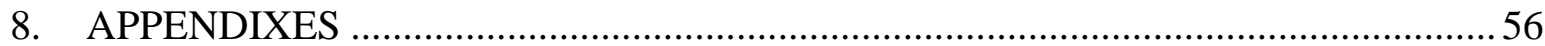




\section{LIST OF FIGURES}

Figure 1 Average age of respondents of current research .............................................27

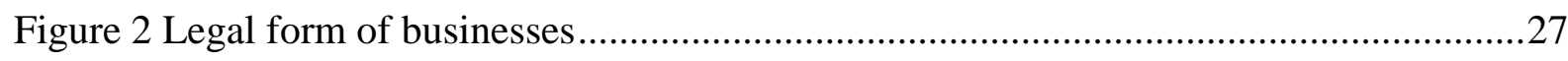

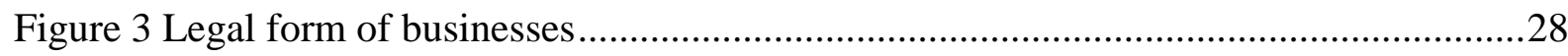

Figure 4 Level of sales revenue for the last financial year .............................................29

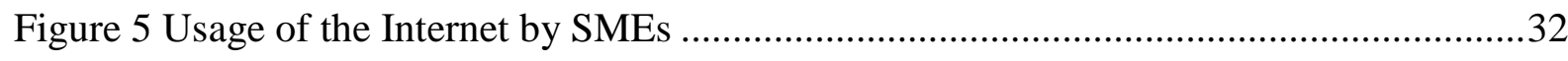

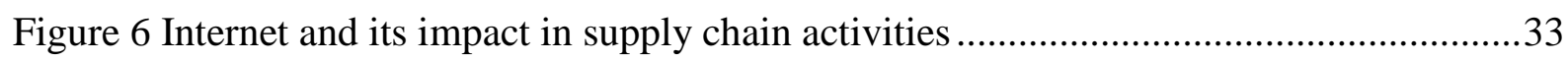

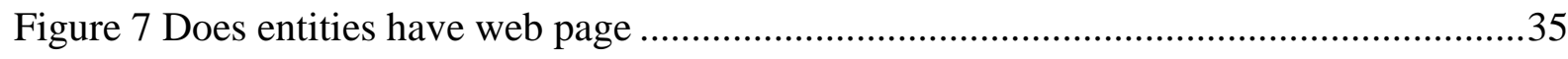

Figure 8 How do you assess the impact of the Internet usage on your business .....................37 


\section{LIST OF TABLES}

Table 1 Information and Communication Technology (ICT) at SMEs.................................31

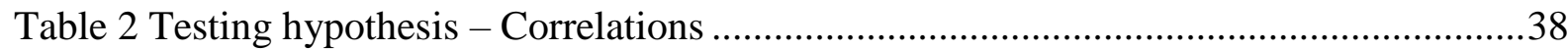

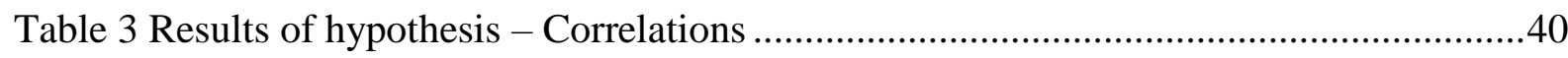




\section{LIST OF ABBREVIATIONS}

Information and Communication Technology - ICT,

Information Technology - IT

Information Systems - IS

WWW - World Wide Web

Transmission Control Protocol/Internet Protocol - TCP/IP protocol

Just-in-Time - JIT

Electronic Data Interchange - EDI

Enterprise Resource Planning - ERP

Advanced Research Project Agency Network - ARPANET

Business-to-Business - B2B

Electronic Commerce - e-Commerce

Small to Medium Enterprises - SME

South East Europe - SEE

European Union - EU

Organisation for Economic Co-operation and Development - OECD

European Bank for Reconstruction and Development - EBRD 


\section{INTRODUCTION}

The way of living among different communities, organizations and enterprises around the World was changed throughout the end of 20th century. The changes are mainly due to the vast use of Information Technology (IT), Information Systems (IS) and the Internet. Therefore, different organizations and enterprises had to shape their form of doing things, known as business model, in order to be able to follow the technological trends, especially changes from mass-production to customer driven economies (El Sawy et al. 1999) and the start of using just-in-time systems (Lea and Min 2003) in order to foster better and faster interaction.

Nevertheless, the changes are not always perceived as a tool to sustain competitiveness in the market which on some occasions makes it hard for an enterprise to survive as was also noted by (Parrilli 2004). However, a well-known term for enterprises as Small to Medium Enterprises (SMEs) defines the companies from 1 to 249 employees as the most unpredictable when it comes to technology and the Internet. This is mainly due to their capabilities to be innovative and to be able to have good quality of product and services (Parrilli and Elola 2012) for their clients, which has had a huge impact on internal and external development factors. Similarly, the SMEs which are based in fragile regions such as the Balkans are influenced by the new technological trends, but, unfortunately with a smaller scale which is related with transition processes in the region. In this way, Kosovo as a country in Balkan Peninsula can be considered as a country which is influenced by the recent technological trends, especially in private sector due to their need for collaboration with different parties outside the country of origin. Furthermore, different academic journals (Cetinkaya et al. (2014), Hervas-Oliver et al. (2016), Aslesen and Harirchi (2015)) stated that the use of innovative approaches through the Internet helped organizations to develop internally and externally, especially by gaining easy access to raw materials, products and their customers to use the benefits within their supply chain activities. In line with this, different authors such as Rasel (2016) and Partanen and Goel (2017) stated that organizations are becoming more punctual by the use of Internet services, mainly to be in touch with customers and suppliers. Though, the author of this thesis found out that there are few researches that were 
conducted within the Balkan Peninsula regarding the current issues of the usage of Internet services. 


\section{LITERATURE REVIEW}

\subsection{Introduction}

Within this chapter the author presents the review of literature with up to date academic discussion regarding the impact of technology and the Internet services within organizations. Through this chapter the author wants to emphasize different perspectives of the new technologies around the World, with a focus on Europe and the Balkan Peninsula.

Furthermore, the literature review chapter is divided in four sub-chapters starting from the impact of SMEs in the society, continuing with the acceptance of new technologies by SMEs as the second part. The third part covers the role of information systems in regards to the development of SMEs and the last part of the literature review covers the Internet services and its impact regarding internal and external development. It is worth mentioning that the findings of this chapter will be compared with the data that were obtained during the in-field research by the author.

\subsection{Impact of Small to Medium Enterprise in a society}

Small to Medium Enterprises (SMEs) are considered as the most important entities within a society. In this way, academics such as Popescu and Benea (2017) as well as (Celuch and Murphy 2010)) stated that the development of a particular state comes at the first stage from the SMEs. By checking the different literature and papers a common description can be found on what an SME is, which in other words is stated:

Definition one:

"Small and medium-sized enterprises (SMEs) represent 99\% of all businesses in the EU. The definition of an SME is important for access to finance and EU support programmes targeted specifically at these enterprises.” (European Commission, n.d.)

Definition two:

"Small and medium-sized enterprises (SMEs) and entrepreneurs are fundamental to innovation, economic growth and job creation, and play a critical role in social cohesion. This 
series provides a means for assessing and improving the performance, design and implementation of SME and entrepreneurship policies, and for sharing policy experiences among OECD member countries and partner economies.. "(OECD 2018c)

As it can be seen from the definition above, their impact within a society is vast, starting from employment trends and continuing with internal and external development of a particular country. In other words, SMEs are considered as the first form of doing business, starting from start-ups (one-man companies with founder male or female) and continuing with other types of doing business, and this may be the reason why the impact of Small to Medium Enterprise in a society is quite large all around the world. For the purpose of the particular thesis, the author will be focused on the region of Balkan Peninsula, with a deeper focus on SMEs in Kosovo.

\subsubsection{SMEs in Balkan Peninsula}

The role of Small to Medium Enterprise within a region or a country has an enormous impact on growth, technological innovation and creativity as well as the creation of different employment opportunities (OECD 2018c). There are several researchers such as BareselBofinger et al. (2015), Ivanovic and Majstorovic (2006), Bartlett et al. (2005) who wrote about the countries of Balkan Peninsula and they mentioned that the main influence of the transition economies of this region has experienced different social changes, such as the change from socialist to a market economy. This change was considered as the most influencer regarding the growth and technological usage, due to its impact on creating new type of jobs (Hultman et al. 2016) as well as more employment opportunities (Anic et al. 2016).

However, the changes from one system to another created different barriers and issues among the countries of this region. In line with this, huge unemployment rates were considered as the down-side of the changes from socialist system to a market economy. Other authors such as, Görgülü (2016) and Perry (2018) stated that the barriers of doing business in Balkan Peninsula were created from the wars on the region within the 90s.

In addition, with the start of $21^{\text {st }}$ century it was found that the doing business and taxation procedures in Kosovo (Abdixhiku et al. 2018), Serbia (Savic 2015), Albania (Sharku and 
Bajrami 2011), Montenegro (Schneider et al. 2010), Macedonia (Garvanlieva et al. 2012), Bosnia and Herzegovina (Lazovic-Pita and Stambuk 2015) were less bureaucratic which was an impulse of growth and a sign of a better business environment, access to finance and better business conditions. In this way, it can be considered that the transition process in this region was not an easy one.

In line with this, about the situation of businesses in Kosovo it can be seen that the private sector is solely based on SMEs Hashani and Badivuku - Pantina (2014) in terms of job growth and it has a huge impact in the economy of the country, which was presented on a report by the European Investment Bank (Gattini and Soljan 2016), were it is seen that in Kosovo's economy SMEs are considered an engine of economic growth, which was also stated by Hashi and Krasniqi (2011). It is worth mentioning that until late 2010, SMEs did not have the attention of the government in Kosovo, especially regarding incentives, which was creating a lot of barriers on cash flow and access to finances.

According to a recent release from the Kosovo Agency of Statistics, it can be seen that the unemployment rate on 2001 was $57.1 \%$ and on 2017 it was 30.5\% (Agjencia e Statistikave te Kosoves 2018) which is an indicator that Kosovo's economy is quite dependent on the SMEs and their employment capabilities. However, the same report shows an increasing tendency of young people between 25 - 40 years old, willing to have their own start-ups in Kosovo, as well as other neighbouring countries and Europe.

Nevertheless, this dependency is not perceived only in countries like Kosovo but also in other developed countries of European Union, where it can be seen that $99 \%$ of 19.3 million enterprises are providing more than 65 million jobs or two thirds of all employment (Lukacs 2005) which shows that the influence of SMEs within a country or region is quite pronounced.

\subsubsection{Opportunities and barriers of SMEs in Balkan Peninsula}

According to the current literature, there aren't any evidences of current trends regarding the focus of SMEs in Balkan. However, within the last twenty years different academics 
and researchers (Brkanovic 2005; Udell, Bakker, and Klpper 2004; Schmeimann 2008) were focused on how SMEs are segmented regarding the structure size and sector.

It is worth mentioning that Brkanovic (2005) and Karajkov (2009) stated that the most spread SMEs in the ex-Yugoslavia countries and Albania are the so-called micro enterprises (with 10 employees or less). In addition, reports by entities such as Organization for Economic Co-operation and Development (OECD 2018b) and World Bank (World Bank 2018b) are showing huge opportunities for SMEs based on the Balkan Peninsula countries to join European Union, where the need for cheaper services and product is seen as the key indicator of SME development. One important factor which is found at the reports of Organization for Economic Co-operation and Development (OECD 2018b) and World Bank (World Bank 2018b) is the high focus of SMEs in trade sector and a very low focus on services offering and manufacturing. Contrary, recent technological changes put emphasis on generating new companies which are focused on services offering and outsourcing services and not a lot in trade sector. Therefore, a recent published thesis by Hoti (2018), shows the great potential of Kosovo regarding the outsourcing advantage and potential for growth, which was also mentioned by Kastrati (2015) and created vast opportunities on the last ten years.

Nevertheless, SMEs in Balkan are mainly financed by individuals or a small group of people which sometimes don't have the funding opportunities. In this way, Brkanovic (2005) considered this fact as the most influential issue which is affecting SMEs not to be focused on service offering and the transition between two types of economies. However, this fact is not connected only with service oriented SMEs but with the manufacturing sector as well since investments on this sector regarding equipment and plants are quite large.

One important factor which is influencing SMEs of the region is the fact that most of the general managers are also the owners of their enterprises with the main focus on growing substantially, which was also found by Hudson et al. (2012) and EBRD (2018).

Still, if one analyses the report by well-known entities such as Organization for Economic Co-operation and Development and World Bank, it can be seen clearly that there was an 
increased tendency in terms of foreign investments within the Balkans which indicates that the doing business environment started to become better and more attractive within the last decade. This trend was presented also by the latest report of OECD (2018a), however, according to a paper published by Karajkov (2009) a lower level of investments was shown due to the global economic crisis which affected all types of enterprises, with a deeper effect on SMEs that had supply chain activities in different parts of the World.

Though, again having in mind the drastic changes that occurred in the last twenty years in the Balkans it can be clearly seen that the environment of doing business was totally reshaped during this transition process. There are different academic views (Karajkov 2009; Martinovic, Sunjic-Beus, and Karisik 2012) which are connecting this twenty years as a prolonged transition and with a deeper impact on the countries' economies by the creation of several states from one-state (ex-Yugoslavia) and connecting the business and managerial culture as the main influential factor which was preventing faster development. In line with this, similar effects can be founded in Kosovo, as the last ex-Yugoslavian country with a very weak economy influenced by the neighbouring counties of the region.

Nevertheless, within Balkan Peninsula the effects mentioned above created a chain of other consequences such as barriers to growth, enormous unemployment rates, and tax barriers to start-ups and SMEs. According to (EBRD 2018) report it can be seen clearly that there is a change in business environment, especially if one compares the report of the years 20002010 where it was a very difficult situation for SMEs, starting from registering the enterprise which took several days, following with poor jurisdiction system and very low access on public procurement by SMEs due to projects which were in favour of some entities. Same concerns and issues where published by Cule and Fulton (2005), where the main focuses were on taxation system, administrative bureaucracy different problems that are associated with financing and other obstacles connected with informal activities.

However, this region is quite powerful in terms of resources and with a great power of young and innovative entrepreneurs who are willing to develop business. In line with this, Thornton (2004) stated that this region is growing quite fast and overcoming the barriers of the transition process by creating new-type of businesses, such as outsourcing (Hoti 2018) 
as well as absorbing more foreign direct investments (Görgülü 2016) which were also presented by (OECD 2018a)

\subsection{Evolution of Information and Communication Technology services}

Information and Communication Technology (ICT) services started to influence the way of how things were done at the end of twentieth century and beginning of twenty first century. This influence was mainly affecting countries which have easier access to resources, such as electricity and the Internet. Therefore, ICT as a whole is considered as one of the most innovative approach which happened in developing countries (Komijani and Mahmoodzadeh 2009).

However, this is not the case for all the regions of the World, since in a research paper by Kayisire and Wei (2016) which has as the main aim to investigate the relative efficiency of ICT adoption and usage in 40 African countries with respect to the utilization of existing socio-economic, infrastructure, and political input factors found out that the trends in Africa are changing for better but still ICT adoption is far away in comparison to other developing countries which are presented by World Bank (2018b) and EBRD (2018).

On the other side, there are research papers (Thongmak 2016; Lechman 2013; Aker, Ghosh, and Burrell 2016) which are presenting different views in terms of ICT usage in different industries and how ICT is being a good tool to influence in a better control by the management as well as lowering costs of storage by the use of Just-in-Time systems (Chaplin et al. 2016).

There are other issues, such as the one of Fries et al. (2003) on which the motivation and managerial capabilities are considered to be the most influential internal factors of technology usage within an enterprises, however, these are not the only issues. For instance, there are issues related to the external factors such as market share, network development and how an enterprise is being perceived by the customers. In line with this, Righi et al. (2017) a research study reveals an assessment of ICT impact within three central nodes in China, the EU28, and the US where it was found out that EU28 has better positioning when it 
comes to exports of products and network development, even though China remains' in a dominant position.

However, going back to the long term perspective of an enterprise, no matter its size, it is crucial to mention that the size of an enterprise is not always a factor when it comes to market share and competitive advantage of a firm, since the outsourcing approach is changing the way and size of enterprises in terms of profitability and sustainability in a rigid market.

\subsubsection{Technological opportunities of SMEs}

With a closer look on reports presented by OECD, EBRD and World Bank (OECD 2018b; EBRD 2018; World Bank 2018b) it can be seen that the role of new technology is having a bigger focus by different economies and societies around Europe, where most of the SMEs are using the opportunities offered by technology especially in improving the business model by using the on-line approach and social media to attract their customers more. In this way, using social media became a need to reach a higher amount of end user at a shorter period, which was also seen by Bouwman et al. (2018) during their empirical study with 338 European SMEs which are using actively social media and big data to innovate their business model.

This tendency is also perceived within the Balkan Peninsula, where most of the enterprises are using technology for their business-to-business and business-to-customer needs. Thus, the usage of technological innovations is considered to be one of the factors to have better growth and to sustain competitiveness in the market. Barth et al. (2011) stated that the recent technology trends in transition economies are having a huge impact on the overall structure and type of enterprises. In line with this, Carr (2003) found out that the hesitancy of business owners and managers about embracing new technologies is one of the challenges which is faced by enterprises.

While analysing the trends and reports from OECD and EBRD(OECD 2018a; EBRD 2018) business registration of the region, it can be seen that there is an increasing tendency of enterprises with the status of individual business and limited liability company, which can be 
also connected with the fact that most of the enterprises are owned and managed by the same person and investments on technology are mainly perceived as costs and not as benefits.

However, the status of enterprise cannot always be considered as the barrier of technology usage. In this was there is a need to understand the influence of technological usage in this region. Reports of different entities (European Commission 2017) identified obstacles and barriers that are influencing the use of new technologies on European level, which is contradictory if reports of Western Balkans (EBRD 2018; World Bank 2018b) shows that the region is moving fast-forward in terms of technology acceptance. This is mainly due to the high foreign direct investment as well as development of infrastructure by the private entities by following international standards. Again, the usage of recent technology should be taken with a degree of concern, since the focus of usage on the reports was mainly connected with larger enterprises which have the capabilities and capacities to invest on innovative solutions because of their financial capacities.

\subsubsection{Importance of location at SMEs}

Within this century to be competitive in the market is not always an easy task since not all enterprises are able to follow the rules of being on the best location nearby their customer. In this way, the success of a particular firm is maximization of profits as the main objective through the use of decision models which are using intangible factors to make their final decision.

Similarly, Pek-Hooi Soh et al. (2004) stated that the location could influence information value in open networks and building contacts is vital for business success, which is affected directly by the use of information technology as a mechanism which is directly influencing business level strategy of the enterprise (Drnevich and Croson 2013) and also influencing the customer value preposition. Nevertheless, there are other researchers which do not agree with the current approach, stating that not all enterprises are using information technology to achieve their goals and strategic direction (Carr 2003). 
However, new approaches through e-business models are perceived as good approaches in different segments by enterprises, especially when it comes to customer relations, marketing and production (Blount et al. 2005) that is also affecting the strategic direction of the enterprise. In a research by Pavic (2011) regarding the e-business and competitive advantage on enterprises located in United Kingdom they were influenced on the same way as they were mentioned by Blount et al. (2005), which in other words is translated as a need to be on-line since the tendency of customers is pushing enterprises to be on the Internet.

Following the views of different authors and researchers, it can be seen clearly that there are other views of the evolution of information and communication technology. Ghani et al. (2009) wrote about the effects on which the integration of recent technology at supply chain management and it was found that there are tremendous benefits by implementing technology in supply chain management, which in other words will increase the activities in a global economy.

In a research by (Stansfield and Grant 2003) it was found that the use of different services offered by new technology have influenced in a positive way the small enterprises in Scotland, which can be seen in other countries of European Union which tells the idea that need for better solutions by recent technology is a must. A critical key to success in developed countries are the country wide strategies regarding technological approach as well as different incentives for better IT infrastructure which was stated also by Barth et al. (2011)

In contrast, the beginning of $21^{\text {st }}$ century for the US region regarding the use of new technologies was not perceived as strategically important, which turned out to have less eservices and overall use of technology (Bharadway and Soni 2007), which was not seen on any of the reports and publications for the Europe region (OECD 2018b; World Bank 2018b; OECD 2018a). Though, Carr (2003) stated that it really depend on the strategic approach, managerial capacities and innovation which is directly influencing the use of information technology and the Internet. Nonetheless, the need for enlarging the operations, increasing customer value proposition, being faster than competitors is fostering the use of new technologies and is not always connected with innovative leaders but mainly with risk takers who are employing new trends. 


\subsection{Impact of Information Systems in SMEs located in Balkan Peninsula}

Overall the influence of politics and changes that occurred even on the economical context during the end of 20th century have influenced and shaped the political systems itself in this region. Technological changes which shaped the industries in which just-in-time systems were implemented in which there was no longer a need to release orders or to wait for order since the suppliers were able to see real time stock of each enterprise. On the other side, the changes created better chances for new type of businesses which didn't request a lot of financial investments but mainly one-man businesses were created, especially to serve as hubs for outsourcing services from abroad.

In this way, new technical terms were introduced to the market and the need for controlled systems was a necessity. Therefore, there was a need that each employee to be connected with each other, first by using the so called Intranet (e.g. A closed network within an enterprise which uses IP to communicate is called Intranet (Migdadi et al. 2012)) which created the option of having a centralized network. Further, by the development of more advanced tools such as Enterprise Resource Planning where organizations are able to control their operations like finance, sales, customer relation through a centralized solution (Denchev 2017) as well as by continuation of the better communication channels through Electronic Data Interchange (EDI) which is a management control system which eliminates the need for middle-man (e.g. Just-In-Time - JIT systems (Dowlatshahi and Taham 2009).

\subsubsection{Impact of Intranet within SMEs}

Technology in general, and intranet in particular cannot give any inputs if they are not implemented nor used (Migdadi et al. 2012). In this way intranet has the main purpose to support easier upload, edit and download files, data tools and work.

The reports of Eurostat (Smihly and Storm 2010) is showing that: "Large enterprises are three times more likely to have intranet, extranet and mobile access to the internet than small enterprises", that tells the idea that mainly large enterprises are using intranet and this can be connected with the security concern and data leakage if the same data is stored out- 
side the enterprise (Torres et al. 2018). However, the low levels of intranet in European Union is sometimes connected with the idea that the communication internally is accomplished via free of charge e-mails or phone application which overcomes the idea of implementing intranet solution.

Nevertheless, authors such as Carr (2003) pointed out that there are critical issues and challenges when it comes to the use of intranet as an interaction tool which are connected with technical and organizational challenges, mainly due to the reluctance of employees or managers. However, if one checks trends of the last five years it can be seen clearly that the intranet in the next decade will become obsolete due to the work in cloud and enterprises need just a good/fast Internet connection and pay for the services and data storage they use online, which was also found by Torres et al. (2018). Though, there are enterprises which are not following recent cloud technology trends and prefer the 'old' way through the use of intranet.

Same trends were perceived on reports of OECD (OECD 2018a) regarding the South East Europe regarding the use of such services by SMEs of this region.

\subsubsection{Advanced Information Systems within SMEs}

The need to have easier cooperation and access was seen as the leading path to the use of advanced information systems such as Enterprise Resource Planning - ERP and Electronic Data Interchange - EDI. In other words, advanced information systems are perceived as a helper and enabler of fostering better business activities all around the globe.

According to a report presented by Eurostat for the period 2011 - 2017 regarding the recent changes ("Digital Economy and Society Statistics - Enterprises - Statistics Explained" n.d.) it can be seen clearly that the Enterprise Resource Planning - ERP and Electronic Data Interchange - EDI are influencing the enterprise in European countries mainly because of the access to the Internet. What is clearly grasped is the fact that the use of ERPs is focused at a larger scale on enterprise of at least 250 persons, where $76 \%$ of them stated that they are using ERP software applications and with a lower percentage of enterprises consisting of 10-49 employees which was $28 \%$, which again brings the idea of medium enterprises not 
willing to invest in high-end solutions due to the idea that the ERP software applications are mainly for large enterprises.

However, a research by Grabski et al. (2011) found out that the use of ERP software application was mainly connected to some of the departments within an enterprise, mainly for finance department and is foreseen as an approach to control processes which are affecting overall performance of the enterprise. Nevertheless, an empirical research by Futekova and Monov (2015) found out that the popular models of implementation of ERP software should be based on identification of factors that may affect the implementation and operation of a particular system prior starting the implementation, these factors may be connected with enterprise structure, turnover, scope and degree of organizational change.

Contrary, other authors such as Tsai et al. (2011) state that the implementation of an ERP solution is quite time consuming with a very low success rate, which is mainly followed by contextual factors of post-implementation such as maintenance and knowledge management. Similar findings were also presented by Laukkanen et al. (2007) where the non-use ERP systems was connected with the lack of knowledge of IT department at SMEs, particularly in small and medium enterprises, which is not the case of large enterprises since they have a different strategic and financial approach when it comes to ERP usage.

On the other side, for the region of Balkan there are few researches and reports regarding the ERP usage by SMEs. In this way, a report by Matijevic and Solaja (2018) for Serbian companies it can be seen that only $18.1 \%$ use ERP from which $59.2 \%$ are large companies, $30.6 \%$ medium-sized companies and only $13.0 \%$ are small companies. In contrast for Macedonia, Albania, Bosnia and Herzegovina there were no official data found in the Internet regarding the use of ERP by SMEs. Whereas in Kosovo according to the previous research for SMEs in manufacturing sector by Aliu and Halili (2013) there was no usage of ERPs nor EDIs by SMEs which were part of the research. Though, for other ex-Yugoslavian countries there are data regarding the use of ERP and are mainly focused on some specific industry, for instance in Croatian wood industry in a research of 22 by Perić et al. (2017) was found that $55 \%$ of them use customized ERP solutions. 
On the other side, another advanced approach of information system is considered the Electronic Data Interchange - EDI which are created with the main aim of fostering greater communication between partners as well as the supply chain management. The idea for such information systems became a need in the $21^{\text {st }}$ century since the enterprises were in desperate need for systems in which all parties are connected, starting from the raw material suppliers until the end of process/product flow, and EDI approach was considered as a need by Craighead et al. (2006).

However, enterprises are investing in EDI to foster a better controlled activities within their business, nonetheless there are researchers such as Clark and Lee (2000) who are considering the use of EDI with a lot of implications with organizational performance. In this way, it can be stated that the use of such systems is mainly dedicated to enterprises with high processing power and employees who are able to interact with their suppliers and customers.

There are only few primary researchers regarding the region of Western Balkans, such as the one by Ketikidis et al. (2008) and reports by World Bank (2015) regarding the use of EDI in railways of the region Therefore, according to current published reports (OECD 2018a; World Bank 2018b) it can be seen that the use of EDI in Western Balkans is quite low in comparison to other regions, such as Europe and United States of America.

\subsection{Impact of Internet in SMEs}

To imagine an enterprise nowadays without technology, especially without having Internet access is nearly impossible. Internet is considered to be game changer in terms of doing business and interacting with clients and partners. It all started as an easier mechanism of communication by the Ministry of Defence at United States of America, through the project called ARPANET (Advanced Research Project Agency Network) (Greenstein 2010) which had its start on 1967 and became a reality when the group of researchers was able to connect four university computers on 1969. ARPANET used the advantage of fractioning the information on so-called packets which were routed on different paths and reconstructed at their final destination, which was the basis of the TCP/IP protocol. 
In this way, the use of the Internet for academic and military purposes was not well-known for public, and the biggest change which is considered as the dawn of Internet is considered the end of 80s and beginning of 90s, were the WWW - World Wide Web was invented and brought new concepts for innovators and visionary entrepreneurs (Black 2016). Nevertheless, the Internet of 90s didn't have a huge impact at the beginning of its usage, similarly nowadays can be considered the effect of block chain technology which is not used in mass yet.

Shaping the way of doing business within the mind set of customers as well as the enterprises was one of the main challenges of the Internet (Black 2016), as well as the highly cost infrastructure of the Internet and computer hardware facilities. Other authors such as (Mu-Li Yang 2014) stated that use of the Internet services is mainly connected with organizational culture.

\subsubsection{Importance of government incentives on Internet infrastructure}

There are different approaches where the Internet is perceived as a cost reduction mechanism and a better tool for decision making, especially in countries where the access to Internet (EBRD 2018) is easier in comparison to countries which are having difficulties in slow adoption by enterprises and peoples which is turning to be an evolutionary manner instead of being a revolutionary approach (Pavic 2011), especially in countries outside Europe where the infrastructure is not well developed and the government are not giving incentives to help the enterprises get on the Internet.

In line with this, Greenstein (2010) and Larsson and Venkatesh (2010) mentioned that the incentives of government can be divided in two parts, on one side through grants to small and medium enterprises which will foster a better interaction among peers connected to supply chain activities and on the other side incentives to Internet Service Providers to enhance the faster Internet connection around the country. Barth et al. (2011) in a paper regarding the financing of SMEs in transition economies stated that the adoption of new type of technologies has to be supported by the governments. It is worth mentioning that, Ministry of Economic Development in Kosovo received a project approval recently by World 
Bank which has as the main focus on offering better access to high-speed and better quality of digital Infrastructure in Kosovo within the period 2018-2023 (World Bank 2018a).

Contrary, Larsson and Venkatesh (2010) with a survey for foreign and domestic software enterprises in Thailand found out that economic fundamentals was perceived as being more important than government incentives in influencing investment decisions, which raised several question in their case of how governmental money be better invested. Also, Pinto (2005) stated that the main problem of government incentives in the Balkan Peninsula region is connected with bureaucratic procedures when it comes to incentives.

\subsubsection{Customer satisfaction on online purchases - e-Commerce}

Business model changes have changed with the use of advanced technologies, especially when SMEs realized that there is a huge need on using e-mails, web-pages (Blount et al. 2005) and lately with the e-commerce (Bharadway and Soni 2007). In this way, the technology started to shape the forms of enterprises, created opportunities for small enterprises (Sun et al. 2012) to compete with bigger enterprises without a need on having offices in several places, which in Hong Kong case showed that customers where satisfied with the content found on online purchases and they use the web-pages of enterprises to purchase or to get information on some specific product.

Moreover, Ratnasingam (2008) mentioned the fact that with the growth of e-commerce known as interaction business-to-consumer (B2C) firms are gaining new customers and are being able to compete with larger firm, even though there are still reluctances of customers using e-commerce instead of shopping physically. Similarly, Kingshott et al. (2018) in a research for New Zealand with sample 336 SMEs found out that quality of service plays a crucial role when it comes to customer satisfaction for both offline and online services.

Furthermore, an empirical research of 222 SMEs by Roy et al. (2017) found out that the retailers mainly went to the so-called e-retailers and suggested information quality and system quality of e-retailer website can be a factor in consumers perceiving e-retailers to be agile, which somehow turns to result in customer loyalty. However, they are facing huge 
competition to secure loyal customers since most of them are purchasing once at an online retailer.

Following the developed countries, SMEs in Balkan Peninsula seems to follow the trends when it comes to being online and increasing their presence around. In a published report by Matijevic and Solaja (2018) the majority of companies in Serbia (99.7\%) have access to the Internet while only $41.4 \%$ are engaged in purchasing online and only $23.8 \%$ are delivering products/services online, which shows that traditional way of customers is still on top of electronic way. On the other side, in Macedonia it can be seen that there is same tendency in two consecutive years, were in 2016 the percentage of enterprises that had broadband Internet connection (fixed or mobile) was 93\% (State Statistical Office of the Republic of Macedonia 2017), whereas the number of people who are using online shopping has been seen a raise from 4\% to 5\% in 2016 (Online C2C e-commerce 2016). Regarding the Internet and e-commerce usage in Bosnia and Herzegovina there are not a lot of data presented, however Internet penetration is about $68 \%$ and most of the companies have web-pages but customer satisfaction in ordering online is quite low (Export.gov 2017a). Regarding the usage of Internet during the year 2017 in Albania there increase from 2016 for $0.4 \%$ respectively in 2017 it was $96 \%$ of enterprises, whereas the use of online shopping via ecommerce platforms does is quite low or $7.7 \%$ of enterprises sold online, which mostly enterprises that are dealing with ICT products are selling online. In contrast for Kosovo, Statistical Agency does not have a separate segment regarding the use of the Internet by SMEs, however in a published report ASK (2018) it can be seen that the customers are mainly focus to buy the goods on store $(54,6 \%)$ rather than buy it online and the other respondents $45.4 \%$ stated that they don't have necessary skills $(12,7 \%)$, delivery issues $(9.1 \%)$ and other issues related with the payment gateways.

Contrary, Croatia is positioned better in terms of customers using online purchases, where in Croatia $76 \%$ of online purchases are done on foreign e-commerce platform, however, satisfaction of customers is higher if a particular online shop has physical premises (Enterprise Europe Network 2018). Followed by Slovenia the customer satisfaction on using ecommerce is higher at domestic platform, where $49 \%$ of purchases are done in local online stores (Export.gov 2017b). 


\subsubsection{Benefits of the Internet tend to outweigh its costs}

Importance of the Internet is clearly seen at any segment of business. In this way, Gitsalis and Pekka-Economou (2014) stated that the Internet is considered as catalyst when it comes to the balance between the power of supplier and customers. In other words the Internet became disrupter of the traditional business models by giving new opportunities on accessing new markets, new raw materials with a cheaper cost (Miyamoto 2017) as well as better interaction opportunities by the use of social media and web pages or connection of them with the customer relationship management of the enterprise (Guha et al. 2018).

On the other side, with the use of the Internet enterprises are using the opportunity on cheaper communication cost via e-mails and other online tools (Miyamoto 2017), which in other words by authors such as Mendo and Fitzgerald (2005) is considered as a driver of change to reach higher standards in terms of performance and job satisfaction.

Furthermore, the Internet has not change only the way of everyday business but it has created huge potential for new type of marketing and online campaigns (Hsu et al. 2008) which in most of the cases are cheaper than the traditional way of marketing. This approach gave huge potentials for Asian countries who has cheap labour and cheap raw materials, through which their orientation on business-to-business (B2B) shake the overall global markets (Miyamoto 2017) when the World virtually became beardless. 


\section{PROBLEM STATEMENT}

Recent technological trends have made a vast change on our everyday life, especially with the use of the Internet solutions. Some of the factors which are influencing the use or nonuse of technology are connected with the Infrastructure and governmental incentives, location of small to medium enterprises as well as the most important factor which is connected with the fact that sometimes entities do not see the benefits of the new technology, especially the use of the Internet.

In response to current trends, this research aims to address the impact of technology, with an emphasis on the Internet through an empirical approach based on the factors mentions above. The main idea of this research is connected with the fact that this particular field does not have any up-to-date researches from any institution within Kosovo as well as the region.

This is why the researcher through a hand delivered questionnaire aimed to get more information about the current trends.

\section{Objectives:}

- Identification of SME structure

- Identification of new technology usage by SMEs

- Identification of internal factors influencing the technology usage, especially Internet

- Identification of external factors influencing the technology usage, especially Internet

- Whether governmental incentives are boosting the usage of the Internet 


\section{METHODOLOGY OF THIS RESEARCH}

As it was stated earlier this empirical study tends to find the impact of Information and Communication Technologies at Small to Medium Enterprises, with a special focus on the Internet. A very important part of a research is the methodology on which the research is based on. Therefore, deeper analyses on research methods were needed in order to be able to understand the research philosophies, strategies and choices within a research which are presented also by Saunders et al. (2009) on the figure below.

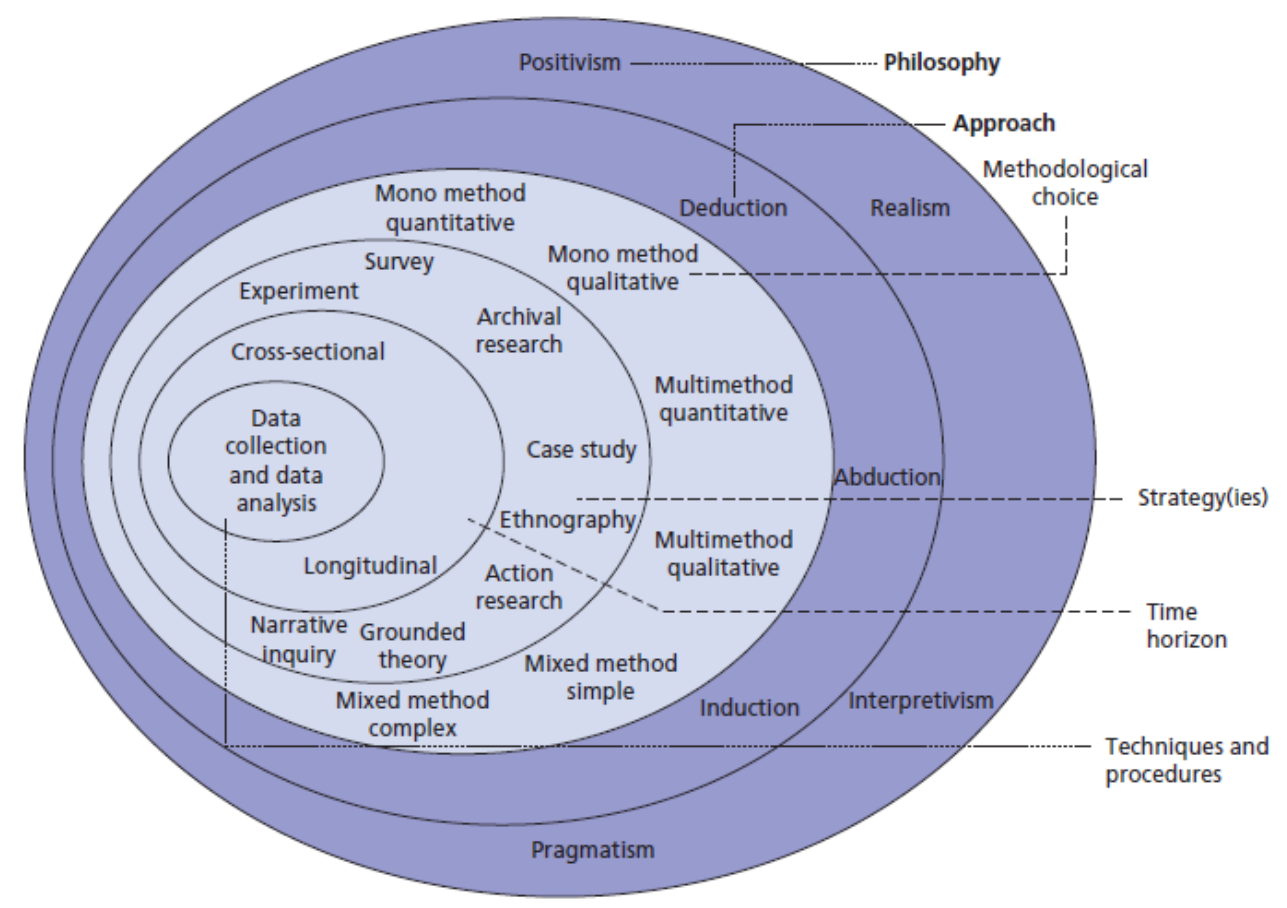

Figure 1. Research Methods for Business Students Saunders et al. (2009)

Well-known authors (Saunders et al. 2009, Heit and Rotello 2010; Lapan et al. 2011) of research methodologies divide the research philosophies into four common used philosophies: realism, interpretivism, pragmatism and positivism. Current research follows an approach of studying the society through the use of statistics in order to understand the impact of the Internet, and for this reason the positivism was selected as the proper philosophy. 
As the above figure shows, in terms of approach of research methodology there are two well-known approaches, the deduction and induction approach. The inductive approach is not used in positivism since inductive reasoning starts with specific instances and goes to conclusion, which is used in case of interpretivism, whereas deductive approach moves from generalized principles to a specific conclusion, which is the case of positivism (Heit and Rotello 2010) and is used on this research. Saunders et al. (2009) calls deductive approach as scientific research since it involves the development of thoughts and theories through precise statistical tests. Others authors such as Lapan et al. (2011) and Lancaster (2007) stated that the deductive approach is a top-down approach which goes from a general view to specific. Another important factor why deductive approach was used on this research is the fact that the researcher is dealing with quantitative analyses and this approach enables the research to quantify the data through statistics.

In regards to research design, current research is connected to descriptive statistics as well as correlations. This research on one side gives the option of comparing different descriptive analysis and to evaluate the data based on variables of the current research, which by well-known authors such as Saunders et al. (2009) is considered as descript-explanatory research design.

Furthermore, different research method authors (Lapan et al. 2011; Saunders et al. 2009, Lancaster 2007) divide research strategies into different sections. For the purpose of this research the author used survey as the most suitable research design based on the sample and complexity of the research as well as due to the fact that the set hypotheses required primary data which needed to be collected through questionnaires through the well-known mono-method or single data collection technique.

A structured questionnaire is used as the main source of gathering the primary data. The initial questionnaire was developed by Stansfield and Grant (2003) and it covered mainly the parts of technological usage by SMEs in Scotland and was adapted partially by Aliu and Missopoulos (2011) for their research regarding ICT usage in transition economies and by Aliu and Halili 2013 for the collecting data of ICT usage in manufacturing industry in Kosovo. Based on prior approval by Stansfield and Grant (2003) the researcher of current re- 
search enhanced and developed other parts of the questionnaire based on the variables of the current research and in accordance with the supervisor suggestions. It is worth to mention that the current research includes five parts, starting from the part which covers demographics, continuing with details of enterprises and factors that are pushing technological usage, as well as market growths and opportunities. Following the trends of current technology used by SMEs and last part included questions which are related to plans and future expansion in terms of new ICT solutions.

\subsection{Data gathering and analysis}

The researcher used an updated list of enterprises from Ministry of Trade and Industry which was published by Open Data Kosovo through which were chosen one hundred and forty SMEs which received the questionnaire. There were two approaches of distributing the questionnaire that the researcher considered. One was to attempt electronically (via email) to distribute the questionnaire, which from previous researches the researcher found out that the response rate will be lower and the other one was to distribute personally at different SMEs all around Kosovo, which was used by the researcher on this research.

In this way, based on research experience of the researcher and the nature of the research, the researcher in discussion with the supervisor decided to follow the approach of visiting the SMEs physically by trying to appoint a meeting with a decision-maker at the SMEs side in order to get correct responses. Mainly the questionnaire was distributed by the researcher at the premises of the enterprises and a period of ten days was given to fulfil the questionnaire to the SMEs. This method was chosen due to the fact that the response rate tends to be higher based on current literature of research methodologies (Lapan et al. 2011, Saunders et al. 2009, Lancaster 2007).

It is worth to mention that the researcher received a good response rate of ninety four fulfilled questionnaires by the decision-makers at SMEs, which in percentage is $67.14 \%$ response rate of the whole sample and the current research suffers from a nonresponse bias of $32.86 \%$. 
Further, the data analysis based on the inputs of the questionnaires needed to be digitally analysed. Therefore, the researcher decided to use Statistical Package for the Social Sciences - SPSS in order to create the database with questions and responses from the respondents. SPPS manuals of Pallant (2016) were used in order to have a deeper view on coding the inputs properly. With SPSS the researcher was able to accomplish descriptive analysis as well as advanced statistical analysis such as correlation in order to accept/reject the hypothesis.

\subsection{Limitations}

The original questionnaire was used in English language, the researcher in close cooperation with supervisor decided to translate the questionnaire in Albanian by using the wellknown method of back translation, which consists of a methodology on which the first translator did the translation from English to Albanian, the second translator did the translation from Albanian to English in order to check if there are changes from the original version and to correct misused words. This process was done from an official translation office in Prishtina.

In addition, the main approach of delivering the questionnaires to owners-decision makers in our region is considered as a difficult since some of the answers can have higher value that their current value and some of the answers can have lower values. The researcher tried to overcome this issue by informing the entities that the results of their questionnaires will be considered and treated in confidentiality by the researcher and will be used only for academic purposes.

\subsection{Hypothesis}

In order to reach the objectives of the current research, the author in close cooperation with the supervisor of the research developed the questionnaire based on the hypothesis set below.

Hypothesis

H1: Having a good location is highly correlated with the necessity of the being online 
H2: Having a good location is highly correlated with the necessity of incentives from government

H3: Having a good location is correlated with benefits of the Internet in comparison to its cost

H4: Necessity of being online is correlated with the necessity of incentives from government

H5: Necessity of being online is correlated the with benefits of the Internet in comparison to its cost

H6: Necessity of incentives from government is correlated with benefits of the Internet in comparison to its cost 


\section{PRESENTATION AND ANALYSIS OF THE RESEARCH}

\subsection{Results regarding the opportunities and decision making in SMEs}

The first part of the questionnaire consisted of data regarding the personal details. In this way, it can be stated that $75 \%$ of the respondents are males whereas $25 \%$ of the respondents are females. These results can be found also at reports of different institutions (OECD 2018a; World Bank 2018b; Agjencia e Statistikave te Kosoves 2018) and also at different reports for the region of Balkan. Mainly the high rates of males in decision making is considered to be due to the bureaucratic procedures (Cule and Fulton 2005) and prejudices if a female is leading an enterprise as well as the barriers which were created by the wars on this region which affected predominantly the way of doing business and sustainability of the enterprises (Görgülü 2016).

Furthermore, based on the respondents of current research it can be seen that there is a high tendency of respondents in between 25-34 years old to have a spirit of managing an enterprise which in percentage is $50 \%$ of the whole population of the research. Other group with of respondents aged between 35-44 occupy $16 \%$ of the whole population, whereas the group less than 25 years old and 44-54 years old occupy $13.8 \%$ of the population and $6.4 \%$ are the respondents between ages of 55-64. Different reports by different institutions (OECD 2018a; World Bank 2018b; Agjencia e Statistikave te Kosoves 2018) show that there is a tendency of young people which are using their skills from academia or have entrepreneurship spirit and create their own enterprise, which are in line with current research.

Other authors connect the high percentage of young people (25-40 years old) in decision making with the technological innovation and recent trends (Popescu and Benea 2017) as well as with transition economies and social changes in Balkan Peninsula (Bartlett et al. 2005). 


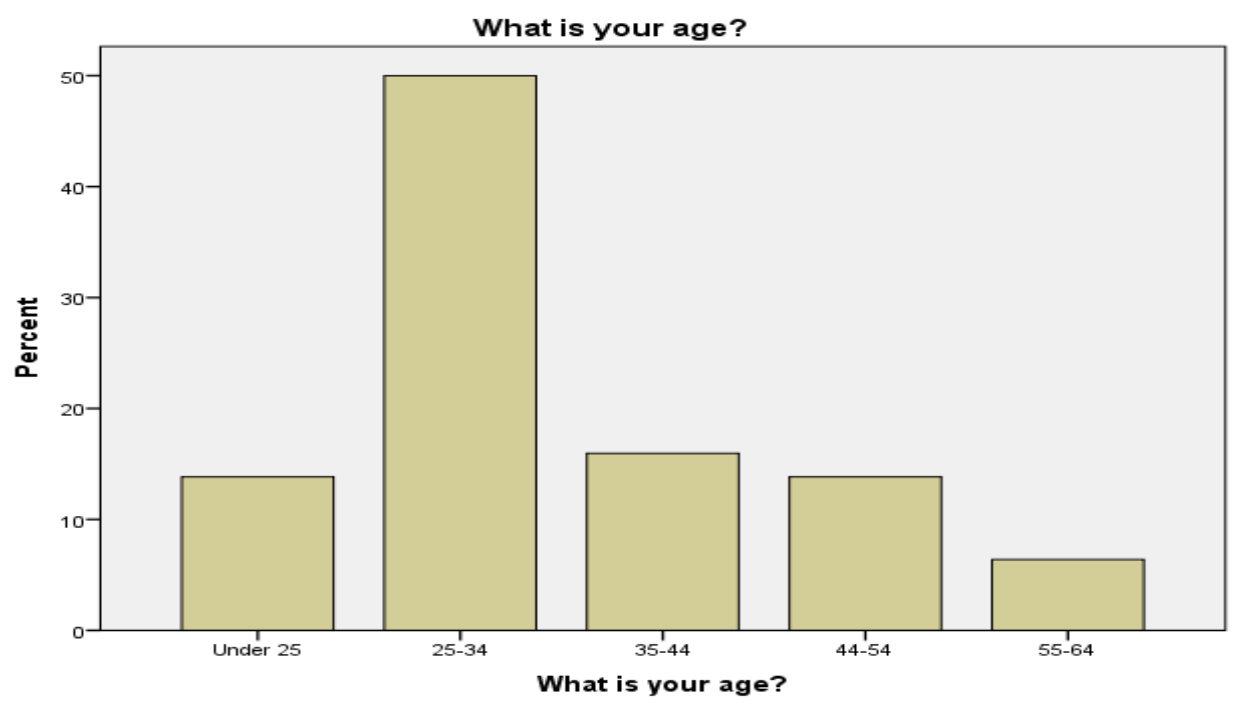

Figure 2. Average age of respondents of current research

In addition, the current research found out that the trends of enterprise creation and legal form of business started to change from single person enterprises to limited liability companies. As the figure below shows, there is a tendency of more than $40 \%$ of the respondents were from limited liability companies and less than $40 \%$ are from single person enterprise.

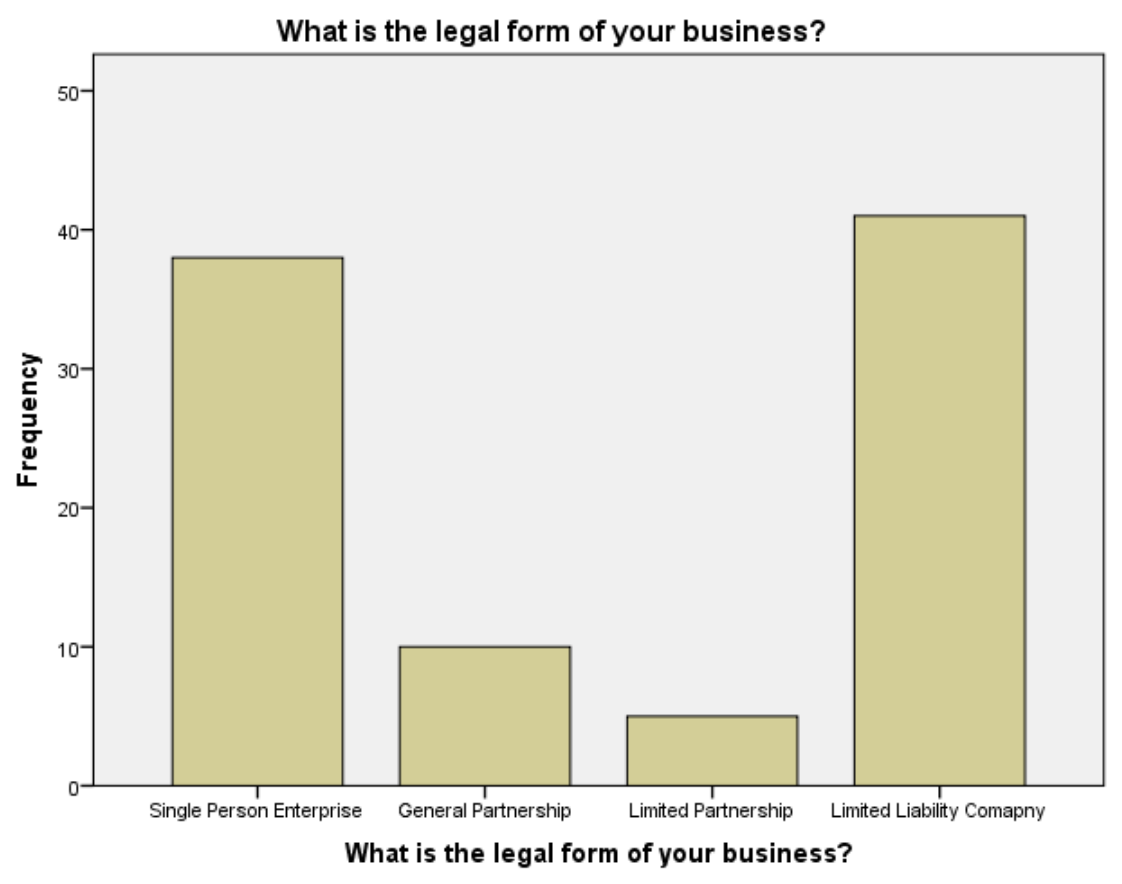

Figure 3. Legal form of businesses 
It is worth to mention that the finding of this research is different from Hudson et al. (2012) and EBRD (2018) where there was seen a higher tendency of single person enterprises in this region, which can be connected with the fact that in recent years in Kosovo there have been changes in business registration law and single person enterprises started to change their status to limited liability companies due to easier tax management. The tendency of individual business and limited liability company found at Balkan Peninsula (OECD 2018a; EBRD 2018) is considered sometimes as a barrier when it comes to investments in technology, since the same person is the owner and the decision maker which does not perceive them as a short term benefits. However, this approach should be not taken for granted since a report of European Commission (2017) identified obstacles and barriers that are influencing the use of new technologies on European level, which is contradictory with reports of Western Balkans (EBRD 2018; World Bank 2018b) which show that the region is moving fast-forward in terms of technology acceptance.

In line with employment enterprise creation, it was found that $80 \%$ of the SME part of this research were founded more than 3 years ago, more than $10 \%$ were founded in between 1 and 3 years ago and less than $10 \%$ were founded in past 12 months.

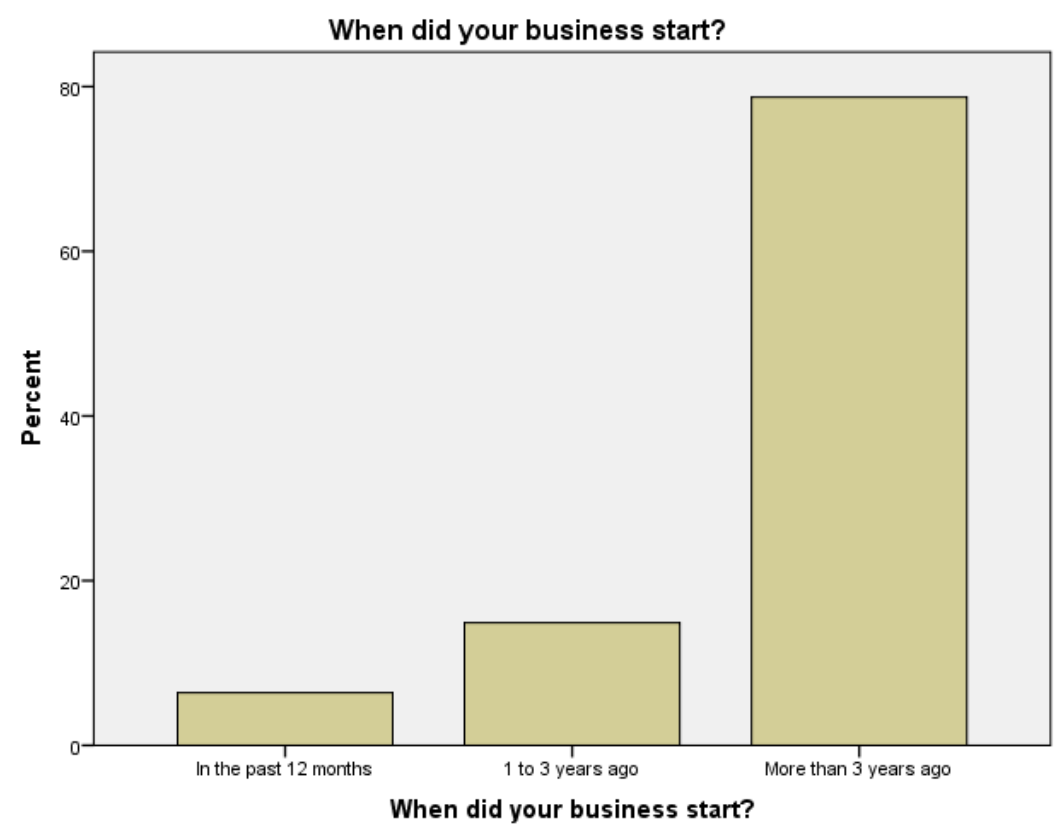

Figure 4. When did the business start 
The results of current research can be connected with the analyses of the reports of Organization for Economic Co-operation and Development and World Bank where it was stated that the foreign direct investments and business environment changes are influencing the stability of the enterprises, and also the global economic changes after 2008 (Karajkov 2009) which influenced indirectly the sustainability of firms. In line with these results, other researchers (Karajkov 2009; Martinovic et al. 2012) stated that the transition of this region has passed and managerial culture is influencing on business stability, with a very low failure rates of SMEs.

Furthermore, it is interesting that the majority of enterprises which are part of this research have a turnover in between of 1 million and 5 million in the last year of operation $(30.85 \%)$, followed $22.34 \%$ by enterprises which has had more than 5 million during the last financial year and other entities occupy the other portion of percentage, as it can be seen on the figure below.

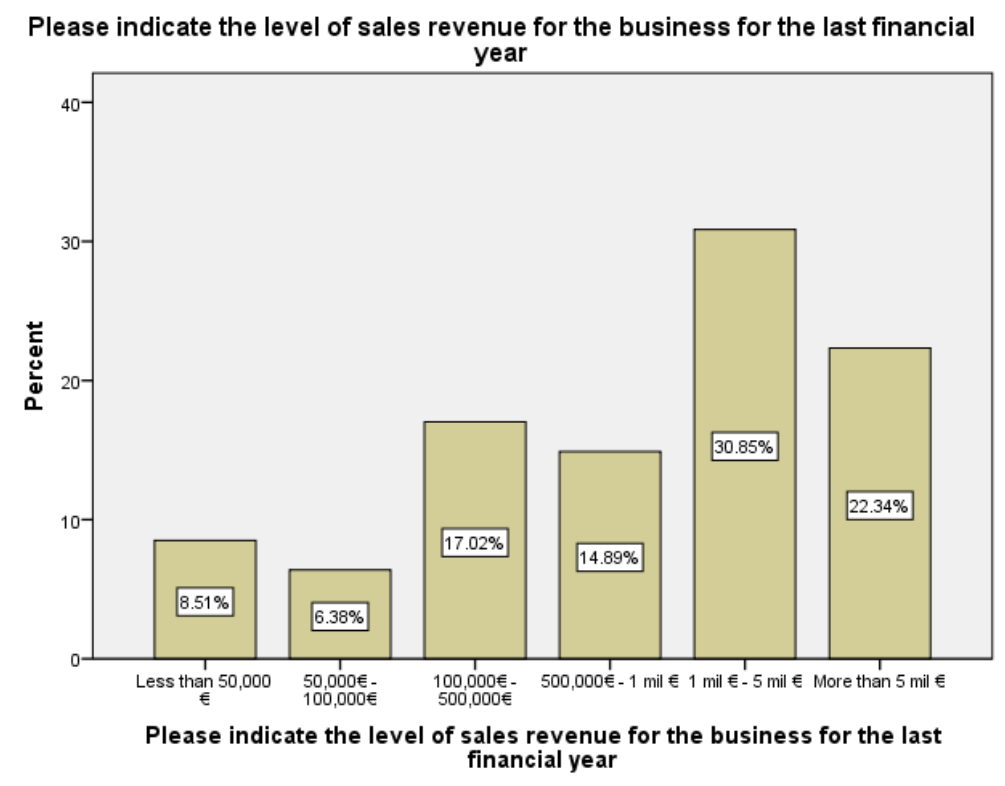

Figure 5. Level of sales revenue for the last financial year

Based on current results it can be seen that the entities with the strongest position are the ones positioned on 1 million to 5 million sales revenues, which in fact is connected with the findings of World Bank (2018b) and EBRD (2018) were the enterprises with this type of 
sales revenue are considered medium-sized enterprises with a good impact on the economic growth of the country. In addition, the entities which has more than 5 million turnover part of this research were less, which is a fact that SMEs in Kosovo are dealing mainly internally and the power of buyers is not that high which is in line with the findings of Agjencia e Statistikave te Kosoves (2018) and which gives the idea why the unemployment rates in Kosovo are in lower scales in comparison to years before.

Another interesting finding is that the SMEs part of current research has a profit rate of more than $5 \%$ at $69.15 \%$ respondents, profit of less than $5 \%$ at $20.21 \%$ respondents, breakeven $2.13 \%$ and loss of $5 \%$ or more $7.45 \%$ of respondents. In addition, the main objective of SMEs part of this research was found to be growing moderately (63.83\%) and a lower percentage $(22.34 \%)$ to grow substantially and only $13.84 \%$ to stay on the same size. The responses of both questions are a good indicator in terms of stability at SMEs and which creates the opportunities for investments in the future, as it was mentioned by Hoti (2018) and by Kastrati (2015). On important finding of this research which differs from the studies of the years 2000-2010 (Schmeimann 2008) is the fact that SMEs of this region have had a focus on growing substantially which on current research was found to be different.

In addition, in terms of main business activity the entities part of current research found out that the main business activity of the entities is retailing and distributing $(58.5 \%$ of respondents), service offering (40.4\%) followed by wholesale (27.7\%), manufacturing $(20.2 \%)$ and information technology $(19.1 \%)$ and transportation $(3.2 \%)$. The current findings in a way explain the fact that the main actors who are influencing the SMEs are in retailing and distributing, as it was mentioned also by World Bank (2018b).

\subsection{Impact of Information and Communication Technology (ICT) at SMEs}

Considering the new century challenges and trends, the researcher has to point out on the questionnaire the questions which were related to technology, starting from basic elements that are fostering the usage of technology, like Personal Computers, e-mail, intranet or other solutions. In line with this, it has been found that all respondents use personal computers 
and e-mails but only $54.3 \%$ are using company intranet for internal purposes and only $2.1 \%$ are using other software's such as Enterprise Resource Planning, EDI or other solutions.

Table 1: Information and Communication Technology (ICT) at SMEs

\begin{tabular}{|l|l|l|}
\hline ICT usage by SMEs & Number of enterprises & Percentage of respondents \\
\hline Personal Computers & 94 & 100 \\
\hline E-mail & 94 & 100 \\
\hline Company Intranet & 51 & 54.3 \\
\hline Others (e.g. LAN, EDI, ERP) & 2 & 2.1 \\
\hline
\end{tabular}

Source: Field researcher by the researcher of current research

Current findings are in line with the findings of Komijani and Mahmoodzadeh (2009) which are stating that the developing countries are trying to pursue technologic changes more, especially countries which are in South East Europe, because for African countries (Kayisire and Wei 2016) it was stated the that ICT adoption is far away in comparison to developing countries.

In addition, the World Bank (2018b) and EBRD (2018) for the Balkan Peninsula are showing similar trends nowadays in terms of ICT usage by SMEs, which was not the fact of eight years ago were it was found by Aliu and Missopoulos (2011) that the technology usage was higher at SMEs in comparison to countries of the region. Another interesting element is that SMEs are still reluctant when it comes to investments in high-end solutions such as ERP, CRM or EDI which are considered by different authors (Thongmak 2016; Lechman 2013; Aker et al. 2016) as a good tool to influence in a better control by the management as well as lowering costs of storage by the use of specific ERP - Just-in-Time system (Chaplin et al. 2016).

Regarding the use of the Internet by SMEs part of this research, majority of the respondents stated that they use Internet for more than 2 years (89.36\%), from 1 to 2 years ago $(5.32 \%)$ and less than $5.5 \%$ are using the Internet for less than a year. Similar findings were found 
regarding the use of Internet services for other purposes, where most of the enterprises (more than 91\%) are using Internet services for other purposes for more than 2 years.

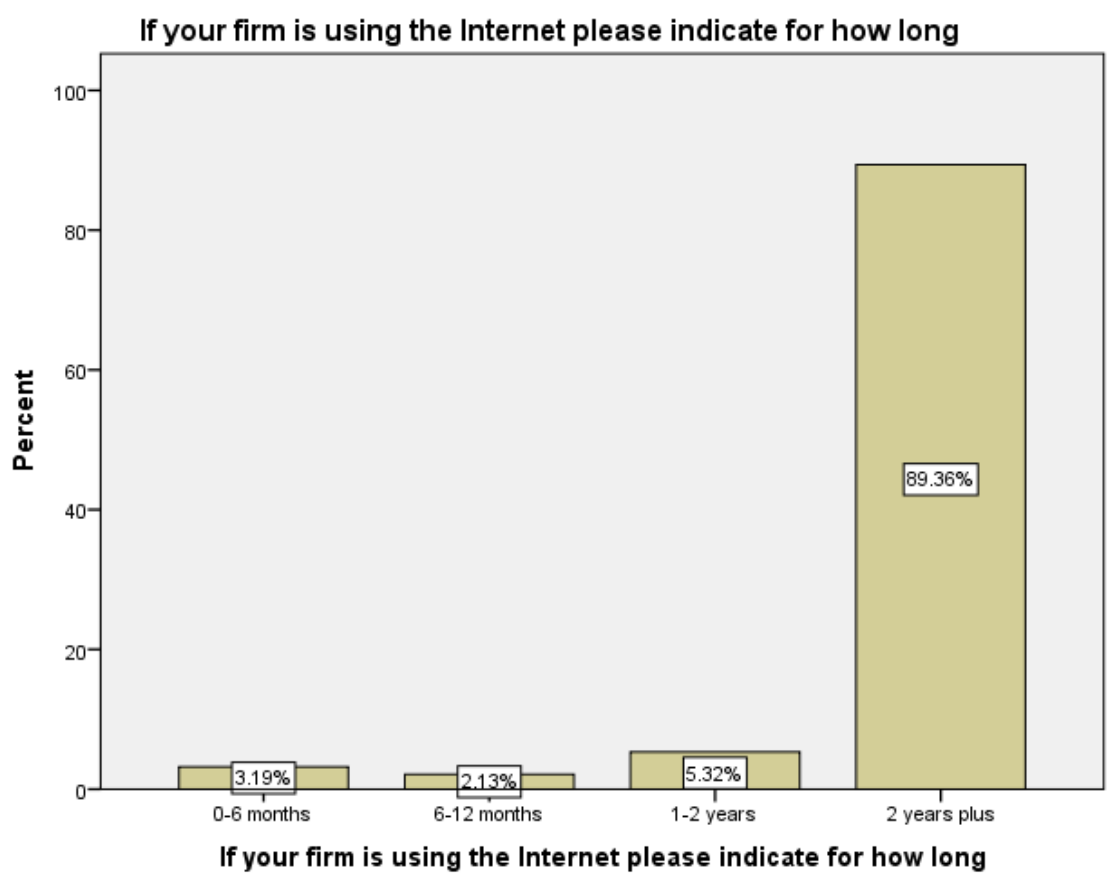

Figure 6. Usage of the Internet by SMEs

The finding of current research are in line with the findings of well-known institutions (OECD 2018b; EBRD 2018; World Bank 2018b) were the role of the Internet is perceived with a bigger focus by different economies and societies around Europe as well as for Balkan Peninsula. Nevertheless, Carr (2003) pointed out that the enterprise model and functioning approach are influencing the decision on embracing new technologies.

In addition, it is worth to mention that the current research found out that the perception of enterprises regarding the impact of the Internet and Information technology services in lowering costs and adding value to their supply chain activities is quite high $(97.9 \%$ of respondents). 


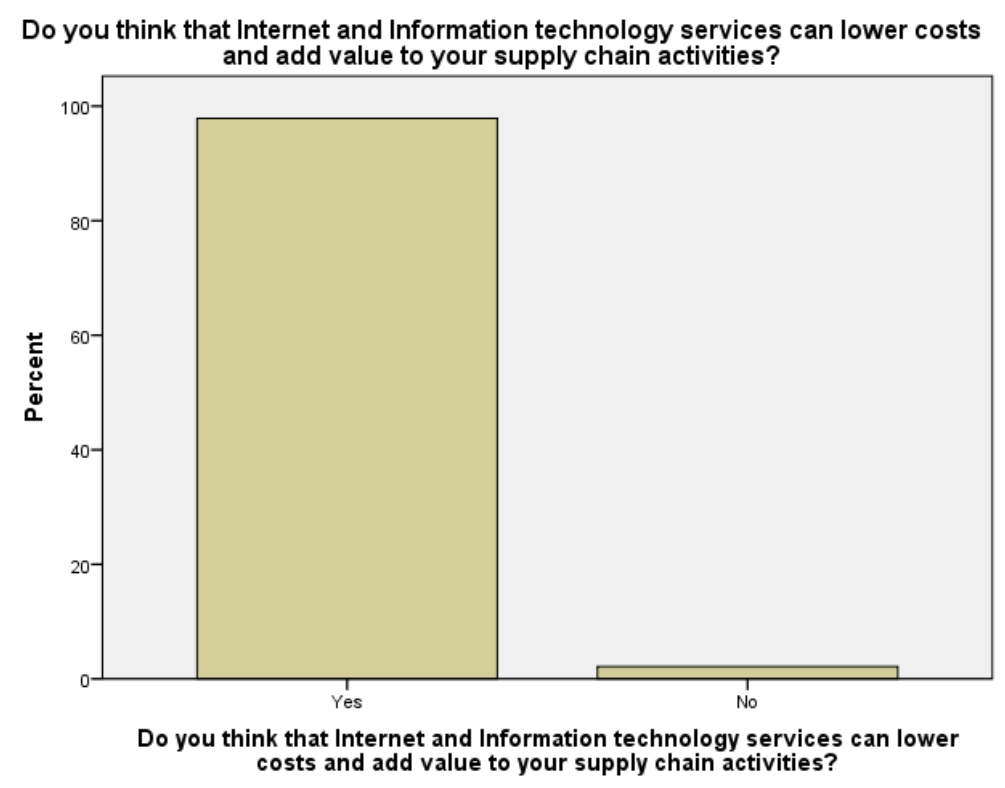

Figure 7. Internet and its impact in supply chain activities

This trend was presented also by the latest report of (OECD 2018a), were SMEs are seen on perceiving the Internet and Information Technology similarly with SMEs in Kosovo. However, contrary is stated in a paper by Karajkov (2009) were it is seen that the level of investment regarding the Internet and Information technology services is at a low level of investments due to global economic crisis which affected all types of enterprises, with a deeper effect on SMEs that had supply chain activities in different part of the World.

\subsection{Internal and external influence on the usage of the Internet and ICT at SMEs}

When it comes to the reasons that influenced the SMEs to use Internet and Information Technology services, the current research found out that more than 53.19\% of the enterprises consider Internet as a very important tool to gain an edge over competitors, $31.91 \%$ consider as an important tool and less than $5.32 \%$ of respondents considered that the Internet is not important or has a marginal importance when it comes to creating competitive advantage. In line with this, it can be said that the need of being and sustaining competitiveness in the market is perceived with the changes that they have to follow in-terms of using new technologies, which was found also by Parilli (2004). 
In addition, regarding the communication with existing customers, more than $85 \%$ of respondents stated that it is quite important for them to use Internet and other information technology services. Also, more than $93 \%$ of respondents stated that they Internet and other information technology services are very important to attract new customers. More than $82 \%$ of respondents stated that the customers requested them to be online. In line with this, different authors such as Rasel (2016) and Partanen and Goel (2017) stated that organizations are becoming more punctual by the use of Internet services, mainly to be in touch with customers and suppliers.

Furthermore, more than $91 \%$ of respondents stated that it is quite important to use the Internet and other information technology services to exploit new markets. More than $80 \%$ of respondents stated that it is very important to use Internet to reach new suppliers. Another interesting response is that more than $89 \%$ of respondents use the Internet to research the Industry and markets. Similarly, 95\% of respondents consider the Internet as valuable tool to keep up with competition. In addition, $76 \%$ of respondents stated that they use the Internet and other technological tools to streamline their operation. The finding of current research regarding the influence of ICT usage are in line with the findings of different academics such as Cetinkaya et al. (2014), Hervas-Oliver et al. (2016), Aslesen and Harirchi (2015) where they stated that the use of innovative approaches through the Internet helped organizations to develop internally and externally, especially by easy access to raw materials, products and their customers to use the benefits within their supply chain activities.

It is worth to mention that $89.4 \%$ of the respondents consider the Internet as a very important tool to research the industry and markets and a vast majority of respondents $(80.8 \%)$ stated that they use the Internet in order to assess its potential benefits and more than $94.7 \%$ stated that they use the Internet to keep up with the competition. The finding part of this paragraph is in line with the findings of different institutions (OECD 2018b; EBRD 2018; World Bank 2018b) when it comes to the use of the Internet with the influence of external factors. 


\subsection{Current and future plans on using innovative solutions offered by the Internet}

The use of new technology within the 21st century is considered a must, especially when it comes to the use of different online tools. In line with this, current research found out that $88.3 \%$ of the respondents possess web page, $3.2 \%$ of the respondents doesn't have web page and $8.5 \%$ are planning in the near future to have a web page. The current results in regards to web page are in line with the findings of Blount et al. (2005).

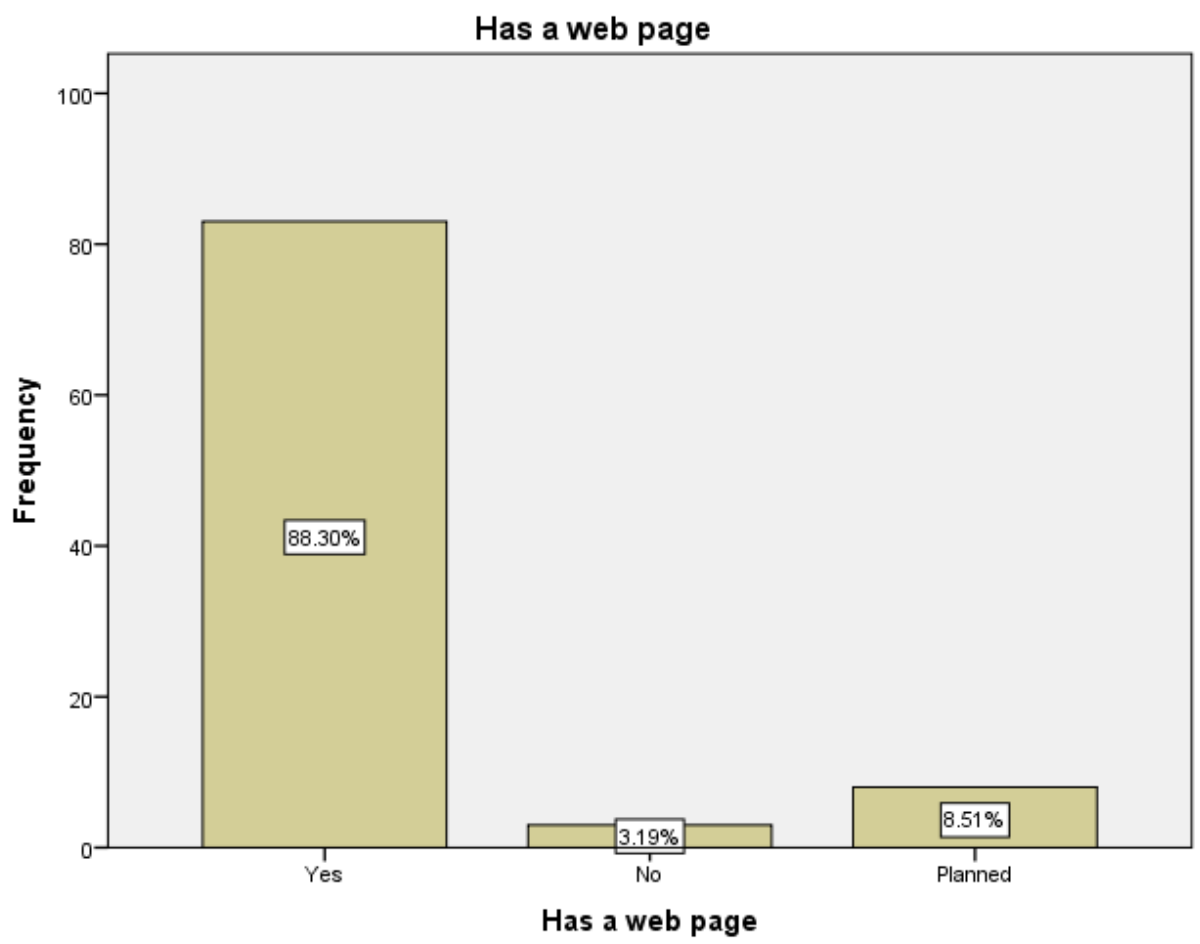

Figure 8. Does entities have web page

In addition, when it comes to the use of the Internet to purchase goods/services or sell them it was found that the selling process is still low in comparison to purchasing goods online, where $63.83 \%$ of respondents declared that they purchase goods or services via the Internet and $42.55 \%$ of respondents stated that they sell goods or services via the Internet.

The low levels of selling online from the company perspective it is connected with the fact that the infrastructure is not well-developed to support selling online as well as the fact that customers are loyal when it comes to purchasing goods/services since they prefer purchasing offline (Roy et al. 2017). However, since most of the respondents possess web page 
they stated that they supply information about the products via the Internet $(94.68 \%$ of the respondents) while $4.26 \%$ of respondents are still not sharing product information via the Internet and $1.06 \%$ is planning in the near future to share information. The current findings are not in line with the finding of Guha et al. (2018) where having a web page is considered as a main source of interaction with different opportunities offered by the Internet.

Furthermore, the current use of the Internet by enterprises is foreseen to have a huge impact when it comes to public bidding. In line with this, the respondents of the current research stated that $78.72 \%$ bid for contract via the Internet, which is considered a good indicator to overcome informal activities (Cule and Fulton 2005) as well as the use of electronic procurement which is the main way of applying for public contract starting from 2019.

\subsection{Interaction with third parties through the use of the Internet}

Another important use of the Internet is connected with the information that can be found for competitors and potential customers. In line with this current research its was found out that $88.3 \%$ of respondents use the Internet to find out about their competitors and $89.36 \%$ of respondents use the Internet to find out about their customers. Also, the use of the Internet to find new suppliers is highly ranked (87.23\%) among respondents of the current research as well as to build business connections (94.68\%). In line with this, different authors such as (Rasel 2016) and (Partanen and Goel 2017) stated that organizations are becoming more punctual by the use of Internet services, mainly to be in touch with customers and suppliers which is in line with the current findings.

Likewise, the statistics in terms of visitors play a crucial role when it comes to the analysis within a business. Nevertheless, the current research found out that only $44.68 \%$ of respondents monitor their number of visitors for analytic purposes, which brings back the situation that was found by Aliu and Halili (2013) where there was no usage of advanced information systems which is offering the analytical tools as well.

In addition, $67 \%$ of the respondents stated that they have a separate on-line subsidiary within their business and $2.13 \%$ are planning to have in the near future, the other part of $30.85 \%$ does not have plans to have an on-line subsidiary within their business. This is a not used potential, since according to the findings of Sun et al. (2012) small enterprises should use 
the power of the Internet to compete with bigger enterprises without a need on having offices in several places.

However, the impact of usage of the Internet on overall business of the respondents it was founded that on $94.68 \%$ of the business the Internet has had positive impact and on $1.06 \%$ of the respondents the Internet has had a negative impact and same percentage don't have any comments, whereas $3.19 \%$ stated that the Internet has had no impact on their business.

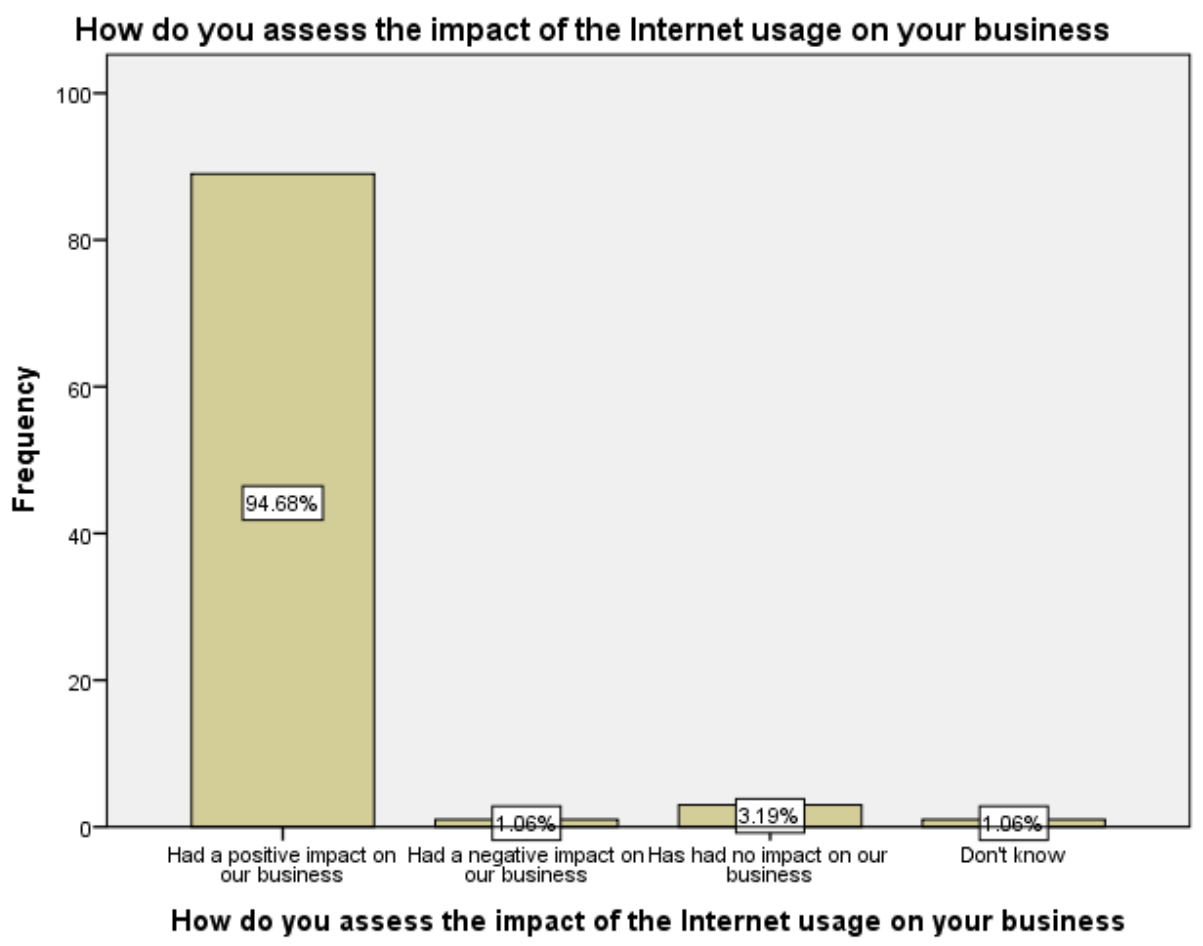

Figure 9. How do you assess the impact of the Internet usage on your business

The impact of the Internet was mentioned also by Barth et al. (2011) where the recent technology trends in transition economies are considered to have a huge impact in overall structure of the enterprises, since a lot of job position are not needed anymore. 


\subsection{Testing hypothesis}

Based on the analysis through SPPSS the following statistics table is generated for the set hypothesis:

Table 2 Testing hypothesis - Correlations

\section{Correlations}

\begin{tabular}{|c|c|c|c|c|}
\hline & $\begin{array}{l}\text { Good loca- } \\
\text { tion is vital } \\
\text { to business } \\
\text { success }\end{array}$ & $\begin{array}{l}\text { Our cus- } \\
\text { tomers in- } \\
\text { creasingly } \\
\text { expect us to } \\
\text { be on-line }\end{array}$ & $\begin{array}{l}\text { The gov- } \\
\text { ernment } \\
\text { should give } \\
\text { more in- } \\
\text { centives to } \\
\text { help firms } \\
\text { get on the } \\
\text { Internet }\end{array}$ & $\begin{array}{l}\text { Benefits } \\
\text { of the } \\
\text { Internet } \\
\text { tend to } \\
\text { outweigh } \\
\text { its costs }\end{array}$ \\
\hline $\begin{array}{l}\text { Good location is vi- Pearson Corre- } \\
\text { tal to business suc- lation } \\
\text { cess } \\
\text { Sig. (2-tailed) } \\
\text { N }\end{array}$ & 94 & $\begin{array}{l}-.043 \\
.677 \\
94 \\
\end{array}$ & $\begin{array}{l}.096 \\
.355 \\
94\end{array}$ & $\begin{array}{l}-.245^{*} \\
.017 \\
94 \\
\end{array}$ \\
\hline $\begin{array}{ll}\text { Our customers in- Pearson Corre- } \\
\text { creasingly expect us lation } \\
\text { to be on-line } & \text { Sig. (2-tailed) } \\
& \mathrm{N} \\
\end{array}$ & $\begin{array}{l}-.043 \\
.677 \\
94 \\
\end{array}$ & 94 & $\begin{array}{l}.352^{* *} \\
.000 \\
94 \\
\end{array}$ & $\begin{array}{l}.297^{* *} \\
.004 \\
94 \\
\end{array}$ \\
\hline $\begin{array}{l}\text { The government Pearson Corre- } \\
\text { should give more lation } \\
\text { incentives to help Sig. (2-tailed) } \\
\text { firms get on the In- N } \\
\text { ternet }\end{array}$ & $\begin{array}{l}.096 \\
.355 \\
94\end{array}$ & $\begin{array}{l}.352^{* *} \\
.000 \\
94\end{array}$ & 94 & $\begin{array}{l}.303^{* *} \\
.003 \\
94\end{array}$ \\
\hline $\begin{array}{l}\text { Benefits of the In- Pearson Corre- } \\
\text { ternet tend to out- lation } \\
\text { weigh its costs } \\
\begin{array}{ll}\text { Sig. (2-tailed) } \\
\mathrm{N}\end{array}\end{array}$ & $\begin{array}{l}-.245^{*} \\
.017 \\
94\end{array}$ & $\begin{array}{l}.297^{* *} \\
.004 \\
94\end{array}$ & $\begin{array}{l}.303^{* *} \\
.003 \\
94\end{array}$ & 94 \\
\hline
\end{tabular}

*. Correlation is significant at the 0.05 level (2-tailed).

**. Correlation is significant at the 0.01 level (2-tailed).

Source: Correlations table generated from IBM SPSS Statistics 22 
Table 2 provides the correlations table where it can be seen that the Pearson correlation among good location is vital to business success and customers expect us to be on-line ( $\mathrm{r}=-$ $0.043, \mathrm{p}=0.677$ ) it can be seen that there is a negative correlation among two variables and the 2-tailed significance is greater than 0.05 where there can be concluded that there is no significant correlation among those two variables, and the hypothesis H1 is rejected.

In addition, correlation among good location is vital to business success and government should give more incentives to help firms get on the Internet $(r=0.096, p=0.355)$, there is weak positive correlation among variables and the 2-tailed significance is greater than 0.05 where there can be concluded that there is no significant correlation among those two variables, and the hypothesis $\mathrm{H} 2$ is rejected.

Further, good location is vital to business success and benefits of the Internet tend to outweigh its costs $(\mathrm{r}=-0.245, \mathrm{p}=0.017)$ it can be seen that there is a weak negative correlation among two variables and the 2-tailed significance is less than 0.05 where there can be concluded that there is correlation among two variables at the $95 \%$ significant. The hypothesis $\mathrm{H} 3$ is accepted at the $95 \%$ significance level which means that good location and Internet tend to outweigh its cost are indirectly related, due to its weak negative correlation which is related to what is stated in literature.

In regards to the variable customers increasingly expect us to be on-line and government should give more incentives to help firms get on the Internet $(r=0.352, p=0.000)$ it can be seen that there is a moderate positive correlation among two variables and the 2-tailed significance is less than 0.05 where there can be concluded that there is correlation among two variables at the $99 \%$ significant level. The hypothesis H4 is accepted at the $99 \%$ significance level which means that necessity of being online is correlated with the necessity of incentives from government are directly related, due to its moderate positive correlation which is related to what is stated in literature.

Furthermore, customers increasingly expect us to be on-line and benefits of the Internet tend to outweigh its costs $(\mathrm{r}=0.297, \mathrm{p}=0.004)$ it can be seen that there is a moderate positive correlation among two variables and the 2-tailed significance is less than 0.05 where there can be concluded that there is correlation among two variables at the $99 \%$ significant level. The hypothesis H5 is accepted at the 99\% significance level which means that necessity of 
being online is correlated the with benefits of the Internet in comparison to its cost are directly related, due to its moderate positive correlation which is related to what is stated in literature. Likewise, The government should give more incentives to help firms get on the Internet and Benefits of the Internet tend to outweigh its costs $(r=0.303, p=0.003)$ it can be seen that there is a moderate positive correlation among two variables and the 2 -tailed significance is less than 0.05 where there can be concluded that there is correlation among two variables at the $99 \%$ significant level. The hypothesis H6 is accepted at the $99 \%$ significance level which means that necessity of being online is correlated the with benefits of the Internet in comparison to its cost are directly related, due to its moderate positive correlation which is related to what is stated in literature.

Table 3 Results of hypothesis - Correlations

\begin{tabular}{|c|c|c|}
\hline \multicolumn{2}{|l|}{ Hypotheses } & \multirow{2}{*}{$\begin{array}{l}\text { Results } \\
\text { Rejected }\end{array}$} \\
\hline Hypothesis 1 & $\begin{array}{l}\text { Having a good location is highly correlated with the ne- } \\
\text { cessity of the being online }\end{array}$ & \\
\hline Hypothesis 2 & $\begin{array}{l}\text { Having a good location is highly correlated with the ne- } \\
\text { cessity of incentives from government }\end{array}$ & Rejected \\
\hline Hypothesis 3 & $\begin{array}{l}\text { Having a good location is correlated with benefits of the } \\
\text { Internet in comparison to its cost }\end{array}$ & Accepted $* *$ \\
\hline Hypothesis 4 & $\begin{array}{l}\text { Necessity of being online is correlated with the necessity } \\
\text { of incentives from government }\end{array}$ & $\begin{array}{l}\text { Accepted } \\
* * *\end{array}$ \\
\hline Hypothesis 5 & $\begin{array}{l}\text { Necessity of being online is correlated the with benefits } \\
\text { of the Internet in comparison to its cost }\end{array}$ & $\begin{array}{l}\text { Accepted } \\
* * *\end{array}$ \\
\hline Hypothesis 6 & $\begin{array}{l}\text { Necessity of incentives from government is correlated } \\
\text { with benefits of the Internet in comparison to its cost }\end{array}$ & $\begin{array}{l}\text { Accepted } \\
* * *\end{array}$ \\
\hline \multicolumn{3}{|c|}{$* * 95 \%$ level of confidence } \\
\hline$* * * 99 \%$ le & confidence & \\
\hline
\end{tabular}

Source: results of hypothesis based on findings from correlations in IBM SPSS Statistics 22 


\section{CONCLUSION, LIMITATIONS AND FUTURE STUDIES}

\subsection{Conclusion}

In order to assess the impact of the new technologies, with emphasis on the Internet at SMEs it was a need to accomplish the current research. The main aim of the current research was to provide a descriptive analysis as well as to test the hypothesis about the impact of the Internet usage at SMEs.

The division chapters of current research was done based on the well-known models of research methods, where on the first chapter the researcher provided information about the general views of SMEs, information technology, information systems and the Internet usage by SMEs. The second chapter is the most-important chapter when it comes to secondary data, since the researcher addressed the issues of the current research with an in-depth literature review starting from the impact of SMEs in a society and continuing with evolution of Information and communication technologies. It is worth mentioning that different reports from well-known institutions were considered during the preparation of literature reviews. Based on chosen research methodology the researcher analysed critically all articles in order to have a views of the phenomena at the particular time-frame. Third chapter includes the problem statement which is crucial for every research since it includes information why this research is done and what it aims to reach and ends with the objectives of the research.

Fourth chapter is dedicated to research methodology, where this research is based on positivism philosophy, and followed a deductive approach as scientific research, mainly by going from a general view to specific by using quantitative analysis through a structured questionnaire in a descript-explanatory research design. The chosen sample of the SMEs was

done through official sources of Ministry of Trade and Industry as well as the Open Data Kosovo, which created the opportunity to have a high response rate of $67 \%$ which was distributed randomly to a sample of 140 SMEs around the territory of Kosovo. In order to conduct the analysis the author used SPSS Statistics 22 which gave the opportunity to test the hypothesis through correlations as well as to provide descriptive statistical analysis. 
This chapter ended with the formation of six hypotheses.

In addition, current research gave interesting analysis when it comes to the opportunities and decision making, including the impact of ICT in SMEs. Also, different internal and external factors that influence the use of ICT were discussed deeply during the presentation and analysis of current research. Also, by this research it was able to measure current and future plans in regards to the use of innovative solutions offered by the new technology as well as to check how the use of the Internet is affecting the interaction with third parties.

Current research gives an up-to date information on what is influencing the use of the Internet by SMEs. In this way the first hypothesis was rejected, which gives the idea that having a good location is not necessary connected to being online, since by being online it is a matter of having good Internet connection and you will reach a specific target group. Likewise, the second hypothesis was rejected and it can be stated that the good location does not necessary gives a specific SMEs access to incentives from government, either as a infrastructure incentives or as a grant incentives. This may be connected with the strategic approach of the government in relation to the development of a particular area.

Third hypothesis was accepted with a week negative correlation which gives the feedback that the costs of the Internet and good location are indirectly connected with each other, which in other words can be said that no matter the location the benefits of the Internet tends to outweigh its cost. Also, fourth hypothesis was accepted with $99 \%$ significance level which means that necessity of being online is correlated with the necessity of incentives from government, in other words the better the infrastructure of the Internet the better the rates of being online. Likewise, fifth hypothesis was accepted with $99 \%$ significance level which explains that being online is correlated with benefits of the Internet in comparison to its costs. Last but not least the sixth hypothesis was also accepted at the $99 \%$ significance level which means that the necessity to be online is correlated with benefits of the Internet in comparison to its cost. In other words, this century is the century of new technological solutions and not matter the costs related to innovative solutions there is a huge need to be online in order to survive. The hypothesis, descriptive analysis and the literature review 
helped the research to improve his knowledge about different issues that were no presented until know for the region of Kosovo.

\subsection{Limitations}

The results of the current research are exposing issues that are valuable for academics and practitioners of this field.

Having in mind the nature of the research on which the number of sample was acceptable and there should be some limitations since in Kosovo the number of registered enterprises is much higher than the current sample, therefore some limitations should be considered, especially when it comes to generalization of the results for the whole enterprises of Kosovo. Even though the targeted number of enterprises was much higher than the filled questionnaires, which should be considered as limitations also because $32.8 \%$ of respondents were not sure about the confidentiality of data and if the data will be used only for academic purposes.

In addition, the questionnaire itself was firstly developed in English and by translating in Albanian; it can be considered that there was a limited usage of different wording, although advanced translation techniques were used in order to overcome such issues.

\subsection{Future studies}

One of the suggestions for further research is connected with a higher sample of enterprises in different regions of Kosovo, especially by changing the way of distributing the questionnaire via online forms and receiving more inputs from SMEs in electronic way. This will foster faster reaction by the researcher and generalization of the whole territory would be possible.

In regards to specific topics, it is quite interesting to focus on the user behaviour when it comes to the use of online services, smart solutions and e-commerce applications. It is worth to mention that, for online services and e-commerce application comparisons the future researchers can use the results of the current study in order to check the similarities and differences. A more in-depth interesting topic would be connected with the age and gender 
of entrepreneurs and the decisions to use or not to use high-end information technology solutions, which will be a new approach of research for aphenomena never investigated according to the current literature and published papers. 


\section{LIST OF REFERENCES}

Abdixhiku, Lumir, Geoff Pugh, and Iraj Hashi. 2018. "Business Tax Evasion in Transition Economies: A Cross-Country Panel Investigation." European Journal of Comparative Economics 15 (1): 11-36.

Agjencia e Statistikave te Kosoves. 2018. "Vjetari Statistikor i Republikës Së Kosovës." http://ask.rks-gov.net/media/4330/vjetari-statistikor-shtator-2018-final.pdf.

Aker, Jenny C., Ishita Ghosh, and Jenna Burrell. 2016. "The Promise (and Pitfalls) of ICT for Agriculture Initiatives." Agricultural Economics 47 (November): 35-48.

Aliu, Albert, and Arbnor Halili. 2013. "The Impact of Information and Communication Technologies as a Tool to Facilitate Growth in the Manufacturing Sector in Republic of Kosovo.” 2013. https://www.sciencedirect.com/science/article/pii/S2212017313001229.

Aliu, Albert, and Fotis Missopoulos. 2011. "An Assessment of Information Technology, Information Systems and Internet Usage among Small to Medium Size Enterprises (SMEs) in a Transition Economy: The Case of Kosovo.” ResearchGate. 2011. https://www.researchgate.net/publication/265641904_An_assessment_of_Informatio n_Technology_Information_Systems_and_Internet_usage_among_Small_to_Mediu m_size_Enterprises_SMEs_in_a_transition_economy_The_case_of_Kosovo.

Anic, Ivan-Damir, Jelena Budak, and Edo Rajh. 2016. "New Information Economy in PostTransition Countries: An Economic Approach to Privacy Concern.” Transformations in Business and Economics 15 (2): 165-78.

ASK. 2018. "Results of the Information and Communication Technology (ICT) Survey, 2017.” 2018. http://ask.rks-gov.net/en/kosovo-agency-of-statistics/add-news/resultsof-the-information-and-communication-technology-ict-survey-2017.

Aslesen, Heidi Wiig, and Gouya Harirchi. 2015. "The Effect of Local and Global Linkages on the Innovativeness in ICT SMEs: Does Location-Specific Context Matter?" Entrepreneurship and Regional Development 27 (9-10): 644-69.

Baresel-Bofinger, Andreas, Panayiotis Ketikidis, and Nikos Zaharis. 2015. "Impediments and Needs of Start-Ups and Investors in South-East Europe for Investment Readiness 
and Growth." Proceedings of the European Conference on Innovation \& Entrepreneurship, January, 54-63.

Barth, James R., Dongyun Lin, and Keven Yost. 2011. "Small and Medium Enterprise Financing in Transition Economies.” Atlantic Economic Journal 39 (1): 19-38.

Bartlett, Will, Nevenka Cuckovic, and Mirela Xheneti. 2005. "INSTITUTIONS, ENTREPRENEURSHIP DEVELOPMENT AND SME POLICIES IN SOUTH EAST EUROPE.” In Enterprise in Transition: International Conference Proceedings: 2005, 1435-54. Ekonomski fakultet Sveucilista u Splitu. http://search.ebscohost.com/login.aspx?direct=true \&db=bth\&AN=26508885\&site=e host-live.

Bharadway, P.N., and R.G. Soni. 2007. "E-Commerce Usage and Perception of ECommerce Issues among Small Firms Results and Implications from an Empirical Study." Ournal of Small Business Management, 501-21.

Black, Michael L. 2016. "The World Wide Web as Complex Data Set: Expanding the Digital Humanities into the Twentieth Century and Beyond through Internet Research." International Journal of Humanities \& Arts Computing: A Journal of Digital Humanities 10 (1): 95-109. https://doi.org/10.3366/ijhac.2016.0162.

Blount, Yvette, Tanya Castleman, and Paula M. C. Swatman. 2005. "E-Commerce, Human Resource Strategies, and Competitive Advantage: Two Australian Banking Case Studies.” International Journal of Electronic Commerce 9 (3): 73-89.

Bouwman, Harry, Shahrokh Nikou, Francisco J. Molina-Castillo, and Mark de Reuver. 2018. “The Impact of Digitalization on Business Models.” Digital Policy, Regulation and Governance 20 (2): 105-24.

Brkanovic, Igor. 2005. "Nonfinancial Obstacles to SME Financing in Serbia." In EU Accession--Financial Sector Opportunities and Challenges for Southeast Europe, edited by Ingrid Matthaus-Maier and J. D. von Pischke, 219-26. Heidelberg and New York: http://search.ebscohost.com/login.aspx?direct=true \&db=eoh\&AN=0825609\&site=eh ost-live.

Carr, Nicholas G. 2003. “IT Doesn’t Matter.” Harvard Business Review 81 (5): 41-49. 
Celuch, Kevin, and Greg Murphy. 2010. "SME Internet Use and Strategic Flexibility: The Moderating Effect of IT Market Orientation." Journal of Marketing Management 26 (1-2): 131-45.

Cetinkaya Bozkurt, Ozlem, and Adnan Kalkan. 2014. "Business Strategies of SMEs, Innovation Types and Factors Influencing Their Innovation: Burdur Model." Ege Akademik Bakis/Ege Academic Review 14 (2): 189-98.

Chaplin, Lara, John Heap, and Simon T. J. O’Rourke. 2016. “Could 'Lean Lite' Be the Cost Effective Solution to Applying Lean Manufacturing in Developing Economies?" International Journal of Productivity \& Performance Management 65 (1): 126-36.

Clark, Theodore H., and Ho Guen Lee. 2000. "Performance, Interdependence and Coordination in Business-to-Business Elect...: EBSCOhost.” 2000.

http://web.a.ebscohost.com/ehost/detail/detail?vid=6\&sid=2d571310-8f75-413fba68-36f33157ea6f\%40sdc-vsessmgr06\&bdata=JnNpdGU9ZWhvc3QtbGl2ZQ\%3d\%3d\#AN=9778038\&db=lxh.

Craighead, C.W., J.W. Patterson, P.L. Roth, and A.H. Segars. 2006. "Enabling the Benefits of Supply Chain Management Systems: An Empirical Stud...: EBSCOhost.” 2006. http://web.a.ebscohost.com/ehost/detail/detail?vid=4\&sid=2d571310-8f75-413fba68-36f33157ea6f\%40sdc-vsessmgr06\&bdata=JnNpdGU9ZWhvc3QtbG12ZQ\%3d\%3d\#AN=19183630\&db=bth.

Cule, M, and M Fulton. 2005. "Some Implications of the Unofficial Economy-Bureaucratic Corruption Relationship in Transition Countries." Economics Letters 89 (2): 207-11. Denchev, Emil. 2017. "The Development of a Model for the Consolidation of Information in Small and Medium-Sized Enterprise (Sme) Clusters." Business Management / Biznes Upravlenie, no. 4 (October): 5-14.

"Digital Economy and Society Statistics - Enterprises - Statistics Explained." n.d. Accessed October 28, 2018. https://ec.europa.eu/eurostat/statisticsexplained/index.php/Digital_economy_and_society_statistics_-_enterprises.

Dowlatshahi, Shad, and Farzam Taham. 2009. "The Development of a Conceptual Framework for Just-In-Time Implementation in SMEs." Production Planning \& Control 20 (7): 611-21. https://doi.org/10.1080/09537280903034305. 
Drnevich, Paul L., and David C. Croson. 2013. "INFORMATION TECHNOLOGY AND BUSINESS-LEVEL STRATEGY: TOWARD AN INTEGRATED THEORETICAL PERSPECTIVE." MIS Quarterly 37 (2): 483-509.

EBRD. 2018. "The EBRD in the Western Balkans."

https://www.ebrd.com/documents/eapa/western-balkans-summit-2018-countryfactsheets.pdf.

Enterprise Europe Network. 2018. "A Guide to E-Commerce in Europe." https://een.ec.europa.eu/sites/default/files/een_guide_ecommerce_2018.pdf.

European Commission. 2017. “Annual Report on European SMEs 2016/2017 - Focus on Self-Employment."

.n.d. "What Is an SME?" http://ec.europa.eu/growth/smes/business-friendlyenvironment/sme-definition_en.

European Investment Bank. 2016. "Assessment of Financing Needs of SMEs in the Western Balkan Countries."

Export.gov. 2017a. "Bosnia - ECommerce | Export.Gov." 2017. https://www.export.gov/article?id=Bosnia-ecommerce.

_. 2017b. "Slovenia - E-Commerce | Export.Gov." 2017. https://www.export.gov/article?id=Slovenia-E-Commerce.

Fries, S, T Lysenko, and S Polanec. 2003. "The 2002 Business Environment and Enterprise Performance Survey: Results from a Survey of 6,100 Firms (No. 84).” No. 84. https://www.researchgate.net/publication/241755940_The_2002_Business_Environ ment_and_Enterprise_Performance_Survey_Results_from_a_Survey_of_6100_Firm s.

Garvanlieva, Vesna, Vlatko Andonov, and Marjan Nikolov. 2012. "Shadow Economy of Macedonia." CEA Journal of Economics 7 (2): 17-36.

Gattini, Luca, and Dragan Soljan. 2016. European Investment Bank. http://www.eib.org/attachments/efs/assessment_of_financing_needs_of_smes_kosov o_en.pdf. 
Ghani, Khurram, Yuserrie Zainuddin, and Farrukh Ghani. 2009. Integration of Supply Chain Management with Internet and Enterprise Resource Planning (ERP) Systems: Case Study., 1 104. Global Business \& Management Research.

Gitsalis, Nikolaos P., and Victoria Pekka-Economou. 2014. “An Evaluation of Perceived Risks and Benefits That Influence the Adoption of a Technological Innovation: The Case of IIOs in SMEs Greek Firms.” International Journal of Economic Research 11 (2): $315-31$.

Görgülü, Emre M. 2016. “The Effects of Foreign Direct Investments on Transition Economies: The Balkans Case.” Journal of Economic \& Social Studies (JECOSS) 6 (2): 23-39.

Grabski, Severin V., Stewart A. Leech, and Pamela J. Schmidt. 2011. “A Review of ERP Research: A Future Agenda for Accounting Information Systems.” Journal of Information Systems 25 (1): 37-78. https://doi.org/10.2308/jis.2011.25.1.37.

Greenstein, Shane. 2010. "The Emergence of the Internet: Collective Invention and Wild Ducks." Industrial and Corporate Change 19 (5): 1521-62.

Guha, Sushmita, Paul Harrigan, and Geoff Soutar. 2018. "Linking Social Media to Customer Relationship Management (CRM): A Qualitative Study on SMEs.” Journal of Small Business and Entrepreneurship 30 (3): 193-214.

Hashani, Muhamet, and Myrvete Badivuku - Pantina. 2014. The Business Environment and Problems of Small and Medium Enterprises in Kosovo 4 (1): 109-30.

Hashi, Iraj, and Besnik Krasniqi. 2011. "Entrepreneurship and SME Growth: Evidence from Advanced and Laggard Transition Economies" 17 (5): 456-87.

Heit, Evan, and Caren M. Rotello. 2010. "Relations between Inductive Reasoning and Deductive Reasoning." Journal of Experimental Psychology: Learning, Memory, and Cognition 36 (3): 805-12. https://doi.org/10.1037/a0018784.

Hervas-Oliver, Jose-Luis, Francisca Ripoll-Sempere, and Carles Boronat Moll. 2016. “Does Management Innovation Pay-Off in SMEs? Empirical Evidence for Spanish SMEs.” Small Business Economics 47 (2): 507-33. 
Hoti, Yllza. 2018. “Outsourcing in Kosovo: An Analysis of Kosovo’s Comparative Advantage and the Potential for Growth.” Prishtina: Rochester Institute of Technology. https://scholarworks.rit.edu/cgi/viewcontent.cgi?article=10971\&context=theses.

Hsu, Li-Ling, Tzu-Chuan Chou, and Tsuen-Ho Hsu. 2008. "Factors That Impact on the Perceived Benefits of Internet International Marketing in Taiwanese SMEs.” Journal of Targeting, Measurement \& Analysis for Marketing 16 (4): 249-60. https://doi.org/10.1057/jt.2008.19.

Hudson, J., C. Williams, M. Orviska, and S. Nadin. 2012. "Evaluating the Impact of the Informal Economy on Businesses in South East Europe: Some Lessons from the 2009 World Bank Enterprise Survey." South East European Journal of Economics and Business 7 (1): 99-110.

Hultman, Martin, Karl Johan Bonnedahl, and Kirstie J O’Neill. 2016. “Unsustainable Societies - Sustainable Businesses? Introduction to Special Issue of Small Enterprise Research on Transitional Ecopreneurs." Small Enterprise Research 23 (1): 1-9.

Karajkov, R. 2009. "Bridging the Gap-Access to Risk Finance for Early-Stage SMEs in Southeast Europe." Skopje: Yes Foundation.

Kastrati, Valon. 2015. “Kastrati, Valon. 'Technological Innovation of Small and Medium Enterprises in Kosovo: Challenges and Barriers.' 4, No. 3 (2015): 145-150.” 4 (3): 145-50.

Kayisire, David, and Jiuchang Wei. 2016. "ICT Adoption and Usage in Africa: Towards an Efficiency Assessment.” Information Technology for Development 22 (4): 630-53.

Ketikidis, Panayiotis, N. Dimitriadis, A. Gunasekaran, and M. Kehajova. 2008. "The Use of Information Systems for Logistics and Supply Chain Management in South East Europe: Current Status and Future Direction - ScienceDirect.” 2008. https://www.sciencedirect.com/science/article/pii/S0305048307000850.

Kingshott, Russel P.J., Piyush Sharma, and Henry F.L. Chung. 2018. "The Impact of Relational versus Technological Resources on E-Loyalty: A Comparative Study between Local, National and Foreign Branded Banks." Industrial Marketing Management 72 (July): 48-58. https://doi.org/10.1016/j.indmarman.2018.02.011. 
Komijani, Akbar, and Mahmood Mahmoodzadeh. 2009. "The Infrastructure, Usage and Spillover Impacts of Information and Communication Technology (ICT) on Economic Growth (EG) in Developing Countries. (In Farsi. With English Summary.)." Iranian Journal of Trade Studies 13 (49): 31-73.

Lancaster, Geoff. 2007. Research Methods in Management. Routledge.

Lapan, Stephen D., MaryLynn T. Quartaroli, and Frances J. Riemer. 2011. Qualitative Research: An Introduction to Methods and Designs. John Wiley \& Sons.

Larsson, Christoffer, and Sundar Venkatesh. 2010. "The Importance of Government Incentives Relative to Economic Fundamentals: The Case of Software Industry in Thailand.” ASEAN Economic Bulletin 27 (3): 312-29.

Laukkanen, Sanna, Sami Sarpola, and Petri Hallikainen. 2007. "Enterprise Size Matters: Objectives and Constraints of ERP Adoption | Request PDF." 2007. https://www.researchgate.net/publication/220306227_Enterprise_size_matters_Objec tives_and_constraints_of_ERP_adoption.

Lazovic-Pita, Lejla, and Ana Stambuk. 2015. "Professional Opinions and Attitudes on Tax Policy in Bosnia and Herzegovina with a Special Focus on the Federation of Bosnia and Herzegovina." South East European Journal of Economics and Business 10 (2): $29-44$.

Lea, Bih-Ru, and Hokey Min. 2003. "Selection of Management Accounting Systems in JustIn-Time and Theory of Constraints-Based Manufacturing." International Journal of Production Research 41 (13): 2879.

Lechman, Ewa. 2013. "New Technologies Adoption and Diffusion Patterns in Developing Countries: An Empirical Study for the Period 2000-2011." Equilibrium: Quarterly Journal of Economics and Economic Policy 8 (4): 79-106.

Lukacs, Edit. 2005. “THE ECONOMIC ROLE OF SMES IN WORLD ECONOMY, ESPECIALLY IN EUROPE.” European Integration Studies 4 (1): 3-12.

Martinovic, Danijela, Mira Sunjic-Beus, and Jasmina Karisik. 2012. "Potencijali i Ogranicenja u Razvitku Poduzetnistva u Bih Na Posebnim Osvrtom Na Sektor Malih i Srednjih Poduzeca. (Development of Entrepreneurship in BH: Prospects and Limita- 
tions, with Special Reference to SME Sector. With English Summary.)." Ekonomska Misao i Praksa 21 (1): 339-62.

Matijevic, Milovan, and Milan Solaja. 2018. "ICT in Serbia - At a Glance 2018 | Vojvodina ICT Cluster.” 2018. https://vojvodinaictcluster.org/ict-in-serbia-at-a-glance-2018-2/.

Mendo, Fernando Alonso, and Guy Fitzgerald. 2005. "A Multidimensional Framework for SME E-Business Progression.” Journal of Enterprise Information Management 18 (6): 678-96.

Migdadi, Mahmoud, Mohammed Khair Abu Zaid, and Omar S. Hujran. 2012. "The Impact of Collaborative Technology on Organisational Performance Through Intranet Use Orientations." Journal of Information \& Knowledge Management 11 (1): 1250003-1.

Milan D. Ivanovic, and Vidosav D. Majstorovic. 2006. "Model Developed for the Assessment of Quality Management Level in Manufacturing Systems." TQM Magazine 18 (4): 410-23.

Miyamoto, Michiko. 2017. "IT-Business Alignment and Resource-Based View of Competitive Advantage: Intangible Assets of Korean SMEs."

Mu-Li Yang. 2014. “A Taiwanese Empirical Study of Online Group Buying from the Perspectives of Organizational Culture and Transformational Leadership." Journal of Electronic Commerce in Organizations 12 (3): 1-11. https://doi.org/10.4018/jeco.2014070101.

OECD. 2018a. "Competitiveness and Private Sector Development, Competitiveness in South East Europe A POLICY OUTLOOK 2018 Pocketbook." https://www.oecd.org/south-east-europe/programme/CO_Pocketbook_2018.pdf.

—. 2018b. "Organisation for Economic Co-Operation and Development Reports 2018." http://www.oecd.org/unitedstates/publicationsdocuments/reports/.

—. 2018c. SME and Entrepreneurship Policy in Indonesia 2018. OECD Studies on SMEs and Entrepreneurship. OECD.

Online C2C e-commerce. 2016. "Online C2C E-Commerce Penetration in Macedonia 2016 | Statistic.” Statista. 2016. https://www.statista.com/statistics/707287/online-c2ccommerce-penetration-in-macedonia/. 
Pallant, Julie. 2016. SPSS Survival Manual: A Step by Step Guide to Data Analysis Using IBM SPSS. Allen \& Unwin.

Parrilli, Mario Davide. 2004. “A Stage and Eclectic Approach to Industrial District Development: Two Policy Keys for 'Survival' Clusters in Developing Countries." European Planning Studies 12 (8): 1115-31.

Parrilli, Mario Davide, and Aitziber Elola. 2012. "The Strength of Science and Technology Drivers for SME Innovation.” Small Business Economics 39 (4): 897-907.

Partanen, Jukka, and Sanjay Goel. 2017. "Interplay between Reputation and Growth: The Source, Role and Audience of Reputation of Rapid Growth Technology-Based SMEs.” Entrepreneurship and Regional Development 29 (3-4): 238-70.

Pavic, Suzana. 2011. "The Creation of Competitive Advantage in SMEs through E-Business (Doctoral Dissertation, University of Sheffield)." UK: University of Sheffield. https://ethos.bl.uk/OrderDetails.do;jsessionid=F6A838C6F55EEB8497BF3515508A 10F8?uin=uk.bl.ethos.555517.

Pek-Hooi Soh, Ishtiaq Pasha Mahmood, and Will Mitchell. 2004. "DYNAMIC INDUCEMENTS IN R\&D INVESTMENT: MARKET SIGNALS AND NETWORK LOCATIONS.” Academy of Management Journal 47 (6): 907-17.

Perić, Ivana, Ana Debelić, and Tomislav Grladinović. 2017. "Enterprise Resource Planning: Case Study of Croatian Wood Processing Companies." More Wood, Better Management, Increasing Effectiveness: Starting Points and Perspective, May, 212.

PERRY, BLISS. 2018. “DE-BALKANIZATION: HOW EUROPE PLANS TO INCORPORATE ITS FINAL FRONTIER.” Harvard International Review 39 (3): 6-7.

Popescu, Felix-Angel, and Ciprian Beniamin Benea. 2017. "INTERNATIONAL ECOMMERCE IN THE EU MEMBER STATES: A GROWING ECONOMIC ACTIVITY." Annals of the University of Oradea, Economic Science Series 26 (2): 33644.

Rasel, Fabienne. 2016. “Combining Information Technology and Decentralized Workplace Organization: SMEs versus Larger Firms.” International Journal of the Economics of Business 23 (2): 199-241. 
Ratnasingam, Pauline. 2008. “The Impact of E-Commerce Customer Relationship Management in Business-to-Consumer E-Commerce." Journal of Electronic Commerce in Organizations 6 (4): 30-46.

Righi, Riccardo, Sofia Samoili, Montserrat Lopez-Cobo, and Giuditta De Prato. 2017. "International ICT Trade Dynamics 2004-2014: An Explorative Network Analysis." DigiWorld Economic Journal, no. 107: 69-94.

Roy, Souvik, Amar Raju, and Santanu Mandal. 2017. "An Empirical Investigation on ERetailer Agility, Customer Satisfaction, Commitment and Loyalty." Business: Theory \& Practice 18 (1): 97-108. https://doi.org/10.3846/btp.2017.011.

Saunders, Mark, Philip Lewis, and Adrian Thornhill. 2009. Research Methods for Business Students. Pearson education.

Savic, Slaven. 2015. "Administrative Obligations of VAT Taxpayers--Serbia versus European Union." Ekonomska Misao i Praksa 24 (1): 245-66.

Schmeimann, M. 2008. "Enterprise by Size Class-Overview of SMEs." 31.

Schneider, Friedrich, Andreas Buehn, and Claudio E. Montenegro. 2010. "New Estimates for the Shadow Economies All over the World." International Economic Journal 24 (4): 443-61.

Sharku, Gentiana, and Etleva Bajrami. 2011. "FOREIGN DIRECT INVESTMENTS AND BUSINESS CLIMATE IN ALBANIA." Young Economists Journal / Revista Tinerilor Economisti 9 (16): 123-31.

Smihly, Maria, and Hendrikus Storm. 2010. "ICT Usage in Enterprises 2009." Eurostat Data in Focus 1: 2010.

Stansfield, M., and K. Grant. 2003. "An Investigation into Issues Influencing the Use of the Internet and Electronic Commerce among Small to Medium Enterprises." Journal of Electronic Commerce Research 4 (1): 15-33.

State Statistical Office of the Republic of Macedonia. 2017. "State Statistical Office of the Republic of Macedonia.” 2017. http://www.stat.gov.mk/Default_en.aspx.

Sun, Hongyi, Pei-Lee Teh, and Anron Chiu. 2012. "An Empirical Study on the Websites Service Quality of Hong Kong Small Businesses.” Total Quality Management \& 
Business Excellence 23 (7/8): 931-47.

https://doi.org/10.1080/14783363.2012.704273.

Thongmak, Mathupayas. 2016. "Youths' Green Information and Communications Technology Acceptance and Implications for the Innovation Decision Process.” Electronic Green Journal 1 (39): 1-25.

Thornton, Judith. 2004. "Small and Medium Enterprises in Transitional Economies." Europe-Asia Studies 56 (8): 1256-57.

Torres, Elton, Gustavo Callou, and Ermeson Andrade. 2018. "A Hierarchical Approach for Availability and Performance Analysis of Private Cloud Storage Services." Computing 100 (6): 621-44. https://doi.org/10.1007/s00607-018-0588-7.

Tsai, Ming-Tien, Eldon Y. Li, Kou-Wei Lee, and Wen-Hui Tung. 2011. "Beyond ERP Implementation: The Moderating Effect of Knowledge Management on Business Performance." Total Quality Management \& Business Excellence 22 (2): 131-44. https://doi.org/10.1080/14783363.2010.529638.

Udell, G.F., M.R. Bakker, and L. Klpper. 2004. "Financing Small and Medium-Size Enterprises with Factoring: Global Growth and Its Potential in Eastern Europe." The World Bank. http://213.154.74.164/invenio/record/14034/files/bakkerwps3342.pdf.

World Bank. 2015. "Rail Electronic Data Interchange in a Border Crossing Point in South East Europe : An Assessment of Options (English) | The World Bank.” 2015. http://documents.worldbank.org/curated/en/747241468147294236/Rail-electronicdata-interchange-in-a-border-crossing-point-in-South-East-Europe-an-assessment-ofoptions.

2018a. "Kosovo - Kosovo Digital Economy (KODE) Project.” PAD2669. The World Bank. http://documents.worldbank.org/curated/en/249951531020771941/Kosovo-KosovoDigital-Economy-KODE-Project.

2018b. "Western Balkans Regular Economic Report: Spring 2018." http://www.worldbank.org/en/region/eca/publication/western-balkans-regulareconomic-report. 


\section{APPENDIXES}

\section{Questionnaire about the impact of the Internet in SMEs}

Dear Sir/Madam,

The questionnaire below is presented to you as a part of a research conducted by Albert Aliu in order to accomplish the tasks and duties part of his master studies at UBT College in Prishtina. The data provided by you will be treated confidentially by the researcher and will be used only for academic purposes.

Therefore, by fulfilling this questionnaire you will help a student to accomplish his final research project.

Thank you for your effort.

\section{SECTION I: Personal Details}

1. Are you female or male?

Female

Male

2. What is your age?

$\begin{array}{ll}\text { Under 25 } & \square \\ 25-34 & \square \\ 35-44 & \square \\ 44-54 & \square \\ \text { 55-64 } & \square \\ \text { Over 65 } & \square\end{array}$

3. Please indicate levels of qualification you have achieved

High School

Professional Qualification

Bachelor degree

Post graduate degree

\section{SECTION II: Details of the business}

4. When did your business start?

(Please tick the appropriate box)

In the past 12 months

1 to 3 years ago

More than 3 years ago

5. What is the legal form of your business?

Single person enterprise

General Partnership

Limited Partnership

Other (Please specify):

Limited liability Company 
6. What are your main business activities?!

$\begin{array}{lll} & \text { Information Technology } & \\ & \text { Manufacturing } & \\ & \text { Retailing and distributing } \\ & \text { Service offering business } \\ & \text { Transportation } \\ & \text { Wholesale } & \\ \text { Other } & \text { (Please } & \text { specify): }\end{array}$

7. How did you start the firm?

Started the business by self / with partners

Bought going concern

Inherited the firm

Management buy-in / buy-out

8. Do you operate the business from?

Your home

Separate business premises

9. How many people have been employed in your firm over the past 3 years?

(Please write in numbers if relevant)

$\begin{array}{lllll} & \text { Full time } & 2009 & 2010 & 2011 \\ \text { (Less than 30 hrs per week) } & - & - & - \\ & \text { Part time } & - & - & -\end{array}$

\section{SECTION III: Markets and Growth}

10. Which of the following would be a major objective for your business for the next three years?
a) To reduce in size
b) Stay same size
c) Grow moderately
d) Grow substantially

11. Please indicate the level of sales revenue for the business for the last financial year
a) Less than $50,000 €$
b) $50,000 €-100,000 €$
c) $100,000 €-500,000 €$
d) $500,000 €-1 \mathrm{mil} €$
e) 1 mil $€-5$ mil $€$
f) More than 5 mil $€$

12. For the last financial year, did your firm operate at (pre-tax profit or loss) as a percentage of turnover?

a) Profit of $5 \%$ or more 
b) Profit of less than $5 \%$

c) Breakeven

d) Loss of less than $5 \%$

e) Loss of more than $5 \%$

\section{Section IV: Technology}

\section{Please indicate which of the following (if any) your firm uses}
a) Personal Computers
b) E-mail
c) Company intranet Other (e.g. LAN, EDI, ERP)
(Please specify)

14. Please indicate how much you agree with each of the following statements

Where

$$
\begin{aligned}
& \mathbf{1}=\text { Strongly Disagree } \\
& \mathbf{2}=\text { Disagree } \\
& \mathbf{3}=\text { Neither agree nor disagree }
\end{aligned}
$$

ly

a) The Internet has no relevance to our business

b) E-commerce is really just a fashion

c) Good location is vital to business success

d) Building contacts is vital for business success

e) The benefits of the Internet tends to outweigh its cost

f) The Internet poses security threats to a business

g) There is an element of fear surrounding the Internet

h) The Internet is mainly for young businesses

i) Our employees will waste time using the Internet

j) Our customers increasingly expect us to be on-line

k) The Internet is a valuable business tool

1) Developing new products and services is

$$
\begin{aligned}
& \mathbf{4}=\text { Agree } \\
& \mathbf{5}=\text { Strongly Agree }
\end{aligned}
$$

Strongly

Strong-

Disagre
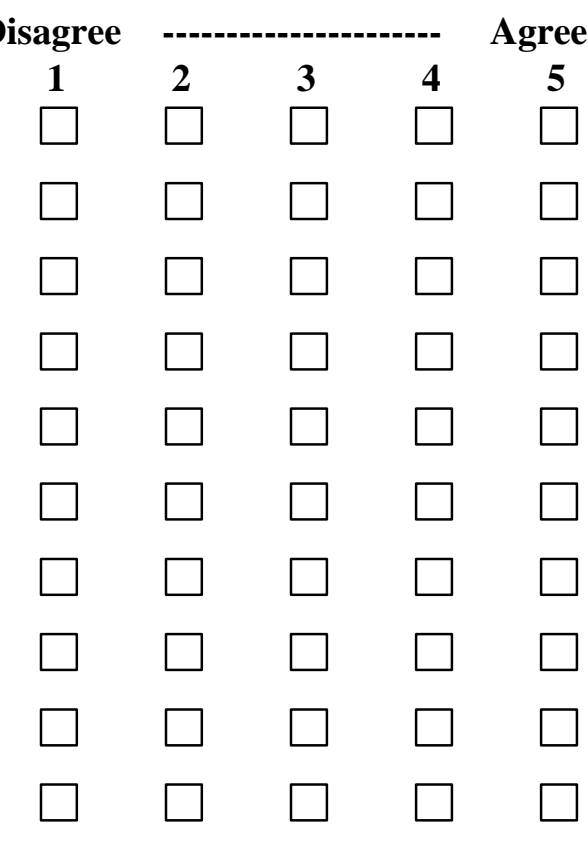
vital for the success of our business

m) Our ability to tap into markets across a wide

geographical area is vital for success

n) The government should give more incentives

to help firms get on the Internet

o) Small companies stand to gain more from using

the Internet than their larger competitors

15. If your firm is using the Internet and/or e-mail please indicate for how long

The Internet

Other IT Services
a) $0-6$ months
b) $6-12$ months
c) $1-2$ years
d) 2 years plus

16. Do you think that Internet and Information technology services can lower costs and add value to your supply chain activities?

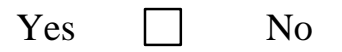

17. Thinking back, how important were the following issues in influencing your decision to use the Internet and/or other Information technology (IT) in the business?

Where

$$
\begin{aligned}
& \mathbf{1}=\text { Not important } \\
& \mathbf{2}=\text { Marginal importance } \\
& \mathbf{3}=\text { Some importance }
\end{aligned}
$$

portant
a) To gain an edge over my competitors
b) Because it is expected in our industry
c) To communicate with existing customers
d) Customers requested on-line access
e) To attract new customers
f) To exploit new markets

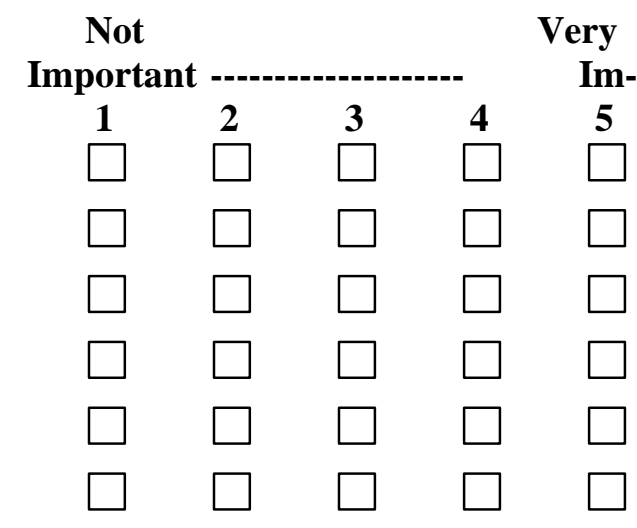


g) To sell on-line

h) To communicate with suppliers

i) Suppliers requested on-line access

j) To search for new suppliers

k) To improve internal communications

1) To streamline internal operations

m) To research the industry and markets

n) To assess its potential benefits

o) My business advisers suggested it

p) To keep up with the competition

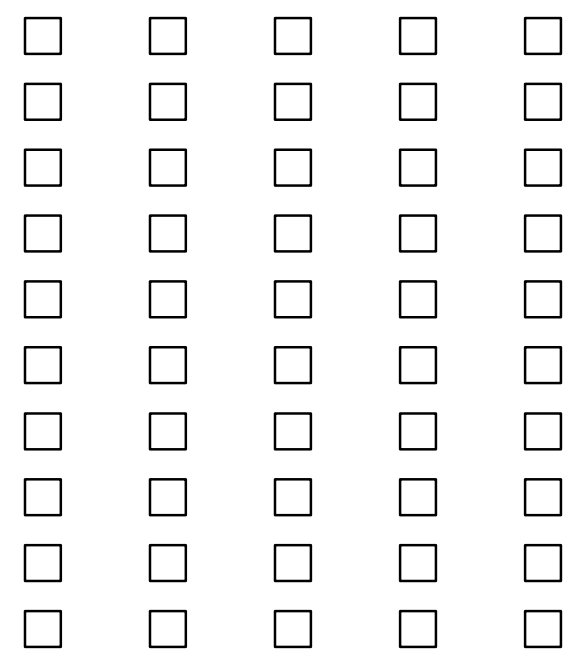

\section{SECTION V: Business activities, current and future plans}

\section{The business:-}

a) Has a web page

b) Purchases goods / services via the Internet

c) Sells goods or services via the Internet

d) Supplies product information via the Internet

e) Bids for contracts via the Internet

f) Uses the Internet to find out about our competitors

g) Uses the Internet to find out about our customers

h) Uses the Internet to find new suppliers

i) Uses the Internet to build business connections

j) Monitors the number of visitors (hits) to our site

k) Has a separate on-line subsidiary

1) Have made staff changes to make use of the Internet

m) Gives staff formal training on using the Internet
Yes

No

Planned
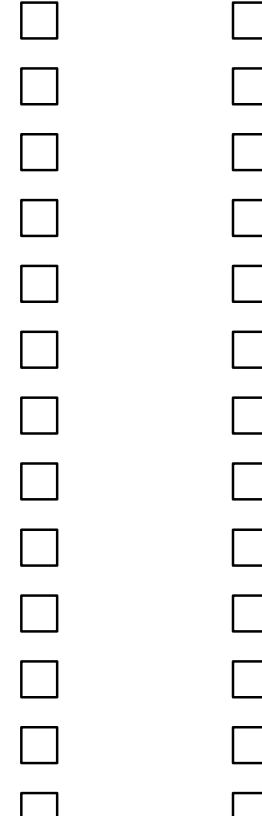

19. How do you assess the impact of the Internet usage on your business
a) Had a positive impact on our business
b) Had a negative impact on our business
c) Has had no impact on our business
d) Don't know
e) Do not use the Internet

20.How do you assess the impact of other Information technology services on your business 

a) Had a positive impact on our business
b) Had a negative impact on our business
c) Has had no impact on our business
d) Don't know
e) Do not use the Internet

21. Do you use the Internet at home for personal use?

Yes $\square \quad$ No

22. Do you use the Internet elsewhere (e.g. library)?

Yes $\square \quad$ No

This section should only be completed by firms using the Internet

23. Approximately how many hours per week do you use the Internet for business purposes?
a) Zero
b) Less than 5
c) 5-10 hours
d) 11-20 hours
e ) More than 20

24. Over the next 2 years, do you expect your use of the Internet to:
a) Decrease
b) Remain the same
c) Increase

25. How would you describe your experience of working with third parties in this area? (e.g. IT consultants, web page designers, etc)
a) Satisfactory
b) Unsatisfactory
c) Not relevant. Have not used third parties 
26. If you have a web page, is it easy to find in the search engines?

$$
\text { Yes } \square \quad \text { No } \square \quad \text { Don't know }
$$

27.Do you actively take steps to get better noticed on the search engines?

Yes $\square \quad$ No $\square \quad$ Don't know

Thank you for assisting in this research project 